\title{
THE MEDICAL FACULTY AT THE UNIVERSITY OF LEIDEN AND ITS GRADUATES FROM THE POLISH-LITHUANIAN COMMONWEALTH
}

\author{
SOME INTRODUCTORY REMARKS*
}

It is well known that the practice of peregrinatio medica (medical travel) was so common in the early modern period that in 1678 the Copenhagen anatomist Thomas Bartholin argued that a well-respected physician is obliged to have his multiannual training abroad:

In our age such great usefulness redounds to the physician from his travel that no one puts much faith in the authority of a physician who has not set foot outside his native land, and although each may have at home in abundance those things which are necessary for medical instruction, nevertheless they ought to be strengthened or increased by a comparison with things abroad ${ }^{1}$.

It is no surprise then that medical students in early modern times were on a constant move; that they travelled across the Continent and the British Isles, and sometimes even overseas ${ }^{2}$, seeking out the best teachers and train-

* Acknowledgements: I am grateful to the Scaliger Institute, which awarded me the Van de Sande Fellowship (2019) to carry out the research project Christoph Gottwald in the Leiden Collection. The research stay in the British Library was financed from the funds of the De Brzezie Lanckoronski Foundation (2020).

1 T. Bartholin, De peregrinatione medica. On medical travel, (1961), p. 45.

${ }^{2}$ For instance, a Lithuanian Alexander Carolus Curtius. Universitaire Bibliotheken 
ers, therefore resembling, to some extent, of course, surgical journeymen in search of the most experienced master craftsmen and noblemen ${ }^{3}$ on their grand tours. During their educational journeys, aspiring physicians were obliged, as a part of their training, to visit: "1. Loca perlustranda, sunt academiae, nosocomia, officinae medicae, horti, montes, sylvae, metalli fodinae, thermae, triremes, castra, amphitheatra anatomica. 2. Morbi \& remedia varia observentur. 3. Consulantur medici clari vel chirurgi: imo \& veterinarii seu hippiatri. 4 . Discat precio vel precibus, sive utilium praeceptorum communicatione, sive exemplorum commonstratione, a dogmaticis juxta \& empiricis" 4 , as it was claimed in the Encyclopedia of Johann Heinrich Alsted published in 1630.

Consequently, the destination, length and scope of educational travels of early modern medical students, regardless of particular instructions published in ars apodemica treatises ${ }^{5}$, depended on many different factors, especially confessional, socio-economic, and political ones, to name only the most obvious; undoubtedly, they varied from one student to another. The travel pattern, however, remained almost always the same. The medical travel lasted a few years. The student matriculated at least at two medical faculties. He graduated from one of them, and afterwards, he continued his educational journey from one place to another and from one master to another, let them be renowned medics, apothecaries, surgeons, collectors,

Leiden (further: UBL), Archieven Senaat en Faculteiten der Leidsche Universiteit (further: ASF) - 414, pp. 54-55. See Appendix.

3 See, for instance, K. Pękacka-Falkowska, H. Bogusz, Christian Heinrich Erndtel, lekarz nadworny Augusta II Mocnego, i jego relacja z podróży uczonej do Anglii i Północnych Niderlandów, in: Lekarz jako autor i bohater literacki, eds. E. Białek, D. Lewera, (2019), pp. 41-43.

4 Encyclopaedia, Septem Tomis Distincta, (1630), col. 2121-2212 (Lib. XXXV: Apodemica, Critica etc.).

5 See, for instance, T. Haye, Lorenz Gryll (d. 1560): A Traveller in the Service of Medical Training, in: Artes Apodemicae and Early Modern Travel Culture, 1550-1700, eds. K. A. E. Enenkel, J. de Jong, (2019), pp. 75-91; T. Bartholin, De peregrinatione medica, (1961); O. Grell, 'Like the bees, who neither suck nor generate their honey from one flower': the significance of the peregrinatio academica for Danish medical students of the late sixteenth and early seventeenth centuries, in: Centres of Medical Excellence? Medical Travel and Education in Europe, 1500-1789, ed. O. P. Grell, A. Cunningham, J. Arrizabalaga, (2010), pp. 171-189; O. Grell, Three seventeenth-century manuals on how and where to study medicine, in: Medicine, Natural Philosophy and Religion in Post-Reformation Scandinavia, ed. O. Grell, A. Cunningham, (2016), pp. 136-152. 
instrument makers, librarians, lithotomists etc. Such 'multistageness' and careful planning of peregrinatio medica was necessary to get to know new knowledge, new skills, and new behaviours that would equip a young man not only to successfully encounter numerous occupational challenges within a short time, but also to respond to the needs and expectations of his patients, clients, 'friends', patrons, and superiors (including, in the latter case, the city authorities). In the $17^{\text {th }}$ and $18^{\text {th }}$ centuries, the medical profession actually required that an adept would be well-informed in many subjects. Thus, he had to acquire not only reliable training in practical medicine, but also to acquire expertise in natural history (especially in botany), chymiatry, anatomy, along with hands-on experience both in surgery and in obstetrics. All this was possible only by way of autopsy along with the study of texts in various centres of medical excellence. Equally important was that an aspiring medic should comprehend the principles of civility along with the multifaceted practice of amicitia and genteelness. It is not surprising then that one of the alumni of Academia Lugduno-Batava (Leiden), Christoph Gottwald from Danzig in Royal Prussia, could explicitly state shortly before his death that the knowledge and experience he had gained during his seven-year educational trip across Europe were beneficial to him throughout his whole life. The same applied to the social connections he had made as a medical peregrinate ${ }^{6}$.

Much has been written about German, English, French, Swiss, and Northern European medical students living in the $17^{\text {th }}$ and $18^{\text {th }}$ centuries ${ }^{7}$. There is also much known about the state of medicine in the Early Modern period in western Europe, whereas medicine in the Polish-Lithuanian Commonwealth along with the mobility of medical students coming from that part of the continent seems to be still an unexplored field of research ${ }^{8}$. Surprisingly, this also applies to the most 'networked' part of Poland, namely to Polish (respectively Royal) Prussia. Also, medical educational travels of

6 K. Pękacka-Falkowska, Wokót kolekcji przyrodniczych w Rzeczpospolitej Obojga Narodów, 1: Christoph i Johann Christoph Gottwaldowie oraz ich gdańskie muzeum, in: Kwartalnik Historii Nauki i Techniki, 2 (2018), pp. 51-97.

7 Centres of Medical Excellence?

8 S. Sokól, Polnische Mediziner in Basel im XVI.-XVII. Jahrhundert, in: Kwartalnik Historii Nauki i Techniki, 5 (1960), pp. 175-190; T. Brzeziński, Polskie peregrynacje po dyplomy lekarskie (od średniowiecza po odzyskanie niepodległości w 1918 r.), (1999), pp. 154-161 (Bibliography). 
future physicians born into burgher families in Danzig (Gdańsk), Thorn (Toruń), Elbing (Elbląg), Graudenz (Grudziądz), etc., are poorly researched and have not been an issue of interest among historians ${ }^{9}$.

This unsatisfactory state of research on medical education of inhabitants of the Polish-Lithuanian Commonwealth may result from at least two factors. As Bernard O'Connor, a Scottish physician to the King of Poland John III Sobieski, claimed in his Description of Poland published at the end of the $17^{\text {th }}$ century, medicine in the Polish-Lithianian Commonwealth was under developed when compared with the one in Western countries:

As for the Practice of Physick in Poland it is but very imperfect. The Doctors there know nothing of the Modern Discoveries in Anatomy and Chymistry, nay, the Materia Medica is hardly known to them, much less improv'd. The Medicines which they use are altogether Galenical, and those always of the worser sort. They are but little acquainted with Modern

9 See, for instance, M. Chachaj, Podróże edukacyjne młodzieży z Prus Królewskich do Bolonii, Sieny i Perugii w XVI i XVII wieku, in: Prusy Książęce i Prusy Królewskie w XVIXVIII wieku, ed. J. Wijaczka, (1997), pp. 195-210; M. Pawlak, Studia uniwersyteckie absolwentów Gimnazjum Elbląskiego w latach 1536-1772, in: Zeszyty Naukowe Uniwersytetu Mikołaja Kopernika. Nauki Humanistyczno-Społeczne, 24 (1967), pp. 112-144; H. Kenkel, Studenten aus Ost- und Westpreußen an außerpreußischen Universitäten vor 1815, anhand der gedruckten Matrikeln, (1981); M. Pawlak, Studia uniwersyteckie młodzieży z Prus Królewskich w XVI-XVIII w., (1988); idem, Wyjazdy młodzieży warmińskiej na studia uniwersyteckie w XVI-XVIII w., in: Komunikaty Mazursko-Warmińskie, 3 (1993), pp. 403-411; idem, Studia uniwersyteckie grudziądzan w epoce staropolskiej, in: Zeszyty Naukowe Wyższej Szkoły Pedagogicznej w Bydgoszczy. Studia Historyczne, 3 (1993), pp. 59-68; idem, W. Długokęcki, Studia uniwersyteckie malborczyków do 1773 roku, (2004). On citizens of Danzig and their medical, educational travels see B. Nadolski, Wyjazdy młodzieży gdańskiej na studia zagraniczne w XVII w., in: Rocznik Gdański, 24 (1965), pp. 195-203; Vitae medicorum Gedanensium Ludwiga von Hammenai Valentina Schlieffa, ed. B. Siek, A. Szarszewski, (2015), pp. 192-253; Pękacka-Falkowska, Wokót kolekcji przyrodniczych; eadem, Freundtschafft die auch nach dem Tod wärt: Daniel Gödtke, Gerard Blaes i zootomia, in: Zapiski Historyczne, 85 (2020) [in press]; eadem, Między Gdańskiem a Toruniem: Georg Seger i anatomia, in: Historia to (nie) fraszka. Studia ofiarowane Profesorowi Krzysztofowi Mikulskiemu w 60. rocznice urodzin, eds. A. Zielińska, M. Targowski, (2020) [in press]; L. Thijssen, Polska Niderlandy: 1000 lat kontaktów, (2003), pp. 184-189 (first published in 1992 as 1000 jaar Polen en Nederland). However, most of these works only enlist medical centres where peregrinants from the Polish-Lithuanian Commonwealth were studying medicine. We know almost nothing about the study programmes, the scope and nature of teaching particular subjects, student life or students' contacts with their teachers and other 'curious people', and thus about things that formed the intellectual profile of the later physician. 
Authors, and particularly with those of our Nation, tho' they have heard of their Names, and will allow that the English Physicians have improv'd Physick beyond any other Nation whatever, but this is still more by hear-say than out of any knowledge they have of us or our Authors [...] the Poles use the same Medicines as we do, yet are they ignorant of the Method of applying them. In their Consultations they advance but little reason, tho' they quote Presidents and Authors for their Practice ${ }^{10}$.

Moreover, O'Connor complained about the low number of physicians practicing in the Crown and Lithuania and about the lack of interest in ars medica and natural history among members of Polish szlachta (nobility), who could afford (almost as the only one) a proper, yet extremely expensive, medical education and training:

As for Physicians in Poland, there are no great number there, and those few that are, for the most part are either French, Italians, or Germans, scarce any of the Natives caring to addict themselves to that Profession; for having little conveniency to improve themselves in it in their own Country, none but the richer sort of Gentry can bear the expence of going to learn it in Foreign Countries, and then such of the Nobility as do Travel are generally either too Lazy or too Proud to apply themselves to what requires so much fatigue to study, and so much judgment afterwards to put in Practise. This, Sir, is the reason why the Poles have hardly any Person thoroughly learn'd in this Profession ${ }^{11}$.

Certainly, one may say that such an opinion was exaggerated and pretty unfair, yet, there are also other historical sources which ascertain us that Poles were actually disinterested in studying medicine and natural history ${ }^{12}$.

10 [B. O'Connor], The history of Poland; vol. 2 in several letters to persons of quality, giving an account of the antient and present state of that kingdom, historical, geographical, physical, political and ecclesiastical [...]: with sculptures, and a new map after the best geographers: with several letters relating to physick / by Bern. Connor [...] who, in his travels in that country, collected these memoirs from the best authors and his own observations; publish'd by the care and assistance of Mr. Savage, (1698), p. 86.

11 Ibid., p. 80.

12 K. Pękacka-Falkowska, Jacob Breyne's horti sicci from 1659 and 1673, in: Zapiski Historyczne, 83 (2018), pp. 47-49. 
The only exception was Royal Prussia, along with its Burgerschaff, which means a township. Yet, even such a statement might be considered misleading, for although O'Connor excluded from his narration German-speaking citizens of Polish Prussian towns, in reality, according to the renowned collector Johann Philipp Breyne, who in 1704 ended his peregrinatio medica and got back to his native land, also the most accomplished city of the region, Danzig, was lagging behind. "As for my person, I am forced to be concealed in this corner of Europe, where [...] people is more interest to ged money"13 than make curious things, he wrote to his English friends Hans Sloane and James Petiver.

Unequivocally, in the $17^{\text {th }}$ and $18^{\text {th }}$ centuries, the physicians to the kings of Poland almost always came from Saxony, France etc. Those, who in turn might be described as 'Poles' were usually Jews or German-speaking Protestant dissenters ${ }^{14}$. Contrary to the view of J. P. Breyne, marred by his stays in Amsterdam and London, many of them (sometimes exhibiting a growing interest in natural history) originate from Polish Prussia. The same applies to the physicians of the Polish magnates and the wealthy noblemen, who willingly used the services of foreign and indigenous medics; they also typically belonged to the group religious dissenters ${ }^{15}$. In the Baroque period and during the Enlightenment, the Polish Catholics of higher social rank hardly ever undertook medical and natural history studies; these simply did not suit the educational ideals and aims of Polish legally privileged noble class, szlachta, whose members, by contrast, were interested in studying law. Admittedly, some Catholic burghers underwent medical training in Padua and Bologna, but after 1600 they rarely graduated with a degree of

13 British Library (further: BL), Sloane Ms 3322, fol. 1r. (original spelling).

14 See, for instance, W. Lisowski, Lekarze w służbie królów i hetmanów polskich, in: Lekarz Wojskowy, 62 (1986), pp. 5-6, 378-385; W. Leitsch, Das Leben am Hof König Sigismunds II. von Polen, 1 (2009), pp. 613-628, 2 (2009), pp. 1019-1037, 1331-1340, 3 (2009), pp. 1557-1562, 1700-1708, 1741-1743; K. Targosz, Jan III Sobieski mecenasem nauk i uczonych, (2012), pp. 336-441; idem, Uczony dwór Ludwiki Marii Gonzagi (1646-1667), (2015), pp. 348-381.

15 S. Kośmiński, Słownik lekarzów polskich: obejmujący oprócz krótkich życiorysów lekarzy Polaków oraz cudzoziemców w Polsce osiadłych, dokładną bibliografię lekarską polską od czasów najdawniejszych aż do chwili obecnej, vol. 1-2 (1883-1885); L. Gąsiorowski, Zbiór wiadomości do historyi sztuki lekarskiej w Polsce od czasów najdawniejszych, aż do najnowszych, vol. 1-4 (1839-1855). 
a doctor of medicine ${ }^{16}$. As a result, the only estimable exception in early modern Poland regarding medical educational trips was aforementioned Royal Prussia with its Burgerschafft and several urban centres in the Crown and Lithuania inhibited by the dissenters. They were the sons of privileged citizens of a few towns in Polish-Lithuania and formed a specific group of medical students on their educational journeys and sometime later, the collective of doctors (of philosophy and) medicine.

Consequently, in this paper, I shall focus on German-speaking students from the Polish-Lithuanian Commonwealth, in particular those from Polish Prussia, who graduated from one of the most renowned Western universities of the early modern period. The focus of this study will thus be the Medical Faculty of the University of Leiden in the $17^{\text {th }}$ and early $18^{\text {th }}$ centuries ${ }^{17}$. Travelling from Polish-Lithuanian territories to the educational, cultural and economic centre in the Dutch Republic and back again, welltrained in anatomy, zootomy, botany, (iatro)chymistry, (iatro)physics, drug formulation, surgery etc., they transferred new knowledge, new skills and new ideas to their home and native land ${ }^{18}$. Yet, it should also be remembered that while on multiannual medical tours, they also disseminated the local Central European medical and natural history knowledge to the Western world, at least to some extent ${ }^{19}$.

16 Brzeziński, Polskie peregrynacje, pp. 140-141, 183-190; H. de Ridder-Symoens, The mobility of Medical Students from the fifteenth to the eighteenth centuries, in: Centres of Medical Excellence?, p. 84.

17 It is worth noting that some Polish Prussian cities like Danzig and Elbing established strong trade ties with the Netherlands; and obviously trade was bringing people, knowledge and various material resources (e.g. artefacts and specimens) from the Polish-Lithuanian Commonwealth to the Dutch Republic and from the Low Countries to the Republic of Poland. The two countries in the late $16^{\text {th }}, 17^{\text {th }}$ and early $18^{\text {th }}$ centuries also had intensive scientific, artistic, architectonic, military, and religious contacts. However, in case of the Crown, it was always Danzig that served as 'aurea porta', that is the golden gate, of the exchange. On Polish-Dutch relations in the $17^{\text {th }}-18^{\text {th }}$ centuries see, for instance, L. Thijssen, Polska Niderlandy; A. Fleischer, Breyne's Botany: (Re-)Locating Nature \& Knowlegde in Danzig, in: Locations of Knowledge in Dutch Contexts, eds. F. J. Dijksterhuis, A. Weber, H. J. Zuidervaart, (2019), pp. 112-115 (the case of Danzig).

Cf. Pękacka-Falkowska, Między Gdańskiem a Toruniem.

19 K. Pękacka-Falkowska, Matthias Ernst Boretius z Mazur i jego promocja doktorska w Niderlandach: $z$ badań nad historia nauczania medycyny w XVIII wieku, in: Wybrane problemy historii medycyny. W kręgu epistemologii i praktyki, eds. A. Magowska, M. Owecki, K. Pękacka-Falkowska, (2020), pp. 211, 214-216. 
In the Renaissance, inhabitants of the Polish-Lithuanian Commonwealth were keen on studying medicine in Italy. The Catholic burghers from Lesser Poland and Mazovia chose that destination occasionally also in the $17^{\text {th }}$ and $18^{\text {th }}$ centuries $^{20}$, whereas the dissenters from Greater Poland, Polish Prussia and Lithuania due to confessional differences matriculated for extensive periods of time at academies of Protestant Europe, visiting Catholic universities and Catholic scholars only during subsequent stages of their educational trips ${ }^{21}$.

From the year 1600 onward, it was the Dutch universities that attracted a great number of Protestant students from the Polish-Lithuanian Commonwealth and especially it was Leiden that had numerous qualities that transformed it into the place of choice for those who wanted to study the higher disciplines of medicine, theology and law ${ }^{22}$. As to medicine, Leiden was an impressive town of scientific productivity, with many private and public libraries, distinguished translators, talented typesetters and notorious

20 Brzeziński, Polskie peregrynacje, pp. 167-172, 179-180, 183-189; L. Rossetti, Dottorati polacchi dal 1600 al 1744 nel Sacro Collegio dei filosofi e Medici di Padova, in: Relazioni tra Padova a la Polonia, (1964), pp. 131-174.

21 See, for instance, [J. P. Breyne], II. Epistola D. J. Phil. Breynij, M. D. Gedanensis, \& Reg. Societ. Lond. Sodal. ad. D. Hans Sloane, M. D. dictee Societatis Secretarium; varias observationes continens, in Itinere per Italiam suscepto, Anno 1703, in: Philosophical Transactions of the Royal Society of London, 27 (1710), pp. 447-459.

22 Yet, it must be remembered that for the Lutherans the University of Leiden was attractive first and foremost as a place of medical training, whereas for the Calvinists, it was also an important centre of theological studies (UBL, ASF-357). In turn, for all new-comers from early modern Poland, regardless of their denomination, Leiden was an interesting touristic site. See, for instance, an opinion of Christian Gabriel Fischer, a preceptor of a law student Nathanael Gerlach of Danzig, who with his mentee spent in Leiden a winter semester 1727/28: "Auch finden Medici nirgends in Teutschland beßere Anführung, zur Anatomie, Chirurgie, Botanic, Physiologie, alß hie, zu Leiden. Daher ist auch der Confluxus von dergl[eichen] Studiosis größer, alß anderwarts. Wer von dießen fleißig ist, und gute Fundamenta mitbringt, kann sich, im Jahr, von hie wohl expediren. Vor Teutsche Juristen aber, und Theologos, taugt diese Academie gar nicht [...]. Aber, es ist der Mühe wohl werth, daß ein reisender Studiosus Theologiae, oder Juris, diesen Orth besuchet, und sich eine weile in Literariis umbsiehet, ehe er von dannen eilet: Welches in wenigen Wochen, bey angenehmen Sommer-Monathen, geschehen kann. Andere JahresZeit, ist den Teutschen sehr beschwerlich, weil das Land dem Scorbut, und Häuffigen Fiebern seht unterworffen ist, welche im Vorjahr, und Herbst, mit allerhand Zufällen sich aüßern”. Biblioteka Politechniki Gdańskiej (further: BPG), Ms D.a.85, vol. II, §. 77, pp. $127-128$. 
publishing houses ${ }^{23}$. It hosted a famous anatomical theatre, along with its vast collections, where even some exhibits from Central Europe were on display $^{24}$. The university had its own botanical (medical) garden, in which among exotic flora even a few Polish and Cassubian plants were introduced $^{25}$. In a university hospital, the St. Caeciliagasthuis, clinical teaching was provided ${ }^{26}$. Moreover, in Leiden, there were numerous instrument makers' workshops like the one run by the Musschenbroeks ${ }^{27}$, an observatory established in $1633^{28}$, and many other sites of knowledge production and exchange. It is no surprise then that from 1597 until 1772 at least 1203 students from the Polish-Lithuanian Commonwealth matriculated at the Academia Lugduno-Batava, attracted by increasing reputation and many highlights of that place. 46\% (557) of them came from Polish Prussia, 45\% (546) from the Crown and only 9\% (100) from Lithuania (Tab. 1).

Naturally, students from Polish Prussia also matriculated at other Dutch universities, for instance, Groningen and Harderwijk (Tab. 2). Nevertheless, it was always the University of Leiden that due to its material, teaching and intellectual advantages attracted the largest number of motivated and ambitious foreigners.

Polish Prussians also willingly attended Dutch illustrious schools, which is often overlooked by scholars. A typical example of such a student is Christian Rudenick, a graduate of Athenaeum Thorunense, who had already studied medicine in Königsberg and Copenhagen, and together with his good friend Niels Stensen got prepared at the Amsterdam Athenaeum

23 D. W. Davies, The World of the Elseviers 1580-1712, (1954); D. Prögler, English Students at Leiden University, 1575-1650: 'Advancing Your Abilities in Learning and Bettering Your Understanding of the World and State Affairs', (2013), passim.

24 T. Huisman, The Finger of God: Anatomical Practice in 17 th Century Leiden, (2008), pp. 55-56.

25 [J. Breyne], Prodromus fasciculi rariorum plantarum, Anno M.DC.LXXIX. in hortis Celeberrimis Hollandiae, praesertim Incomparabili \& Nobilissimo illo Florae Pandocheo Illustrissimi atqve Excellentissimi Domini, Domini Hieronymi van Beverningk etc. observatarum a Jacobo Breynio, Gedanensi [...], (1680), pp. 29 (cicutaria Cassubica), 40 (laserpitium daucoides Prutenicum), 52 (tripolium).

26 Huisman, The Finger of God, pp. 112-118.

27 More on the Musschenbroeks see P. R. De Clercq, At the Sign of the Oriental Lamp, the Musschenbroek Workshop in Leiden, 1660-1750, (1997).

28 W. de Sitter, Short History of the Observatory of the University at Leiden, 1633-1933, (1933). 


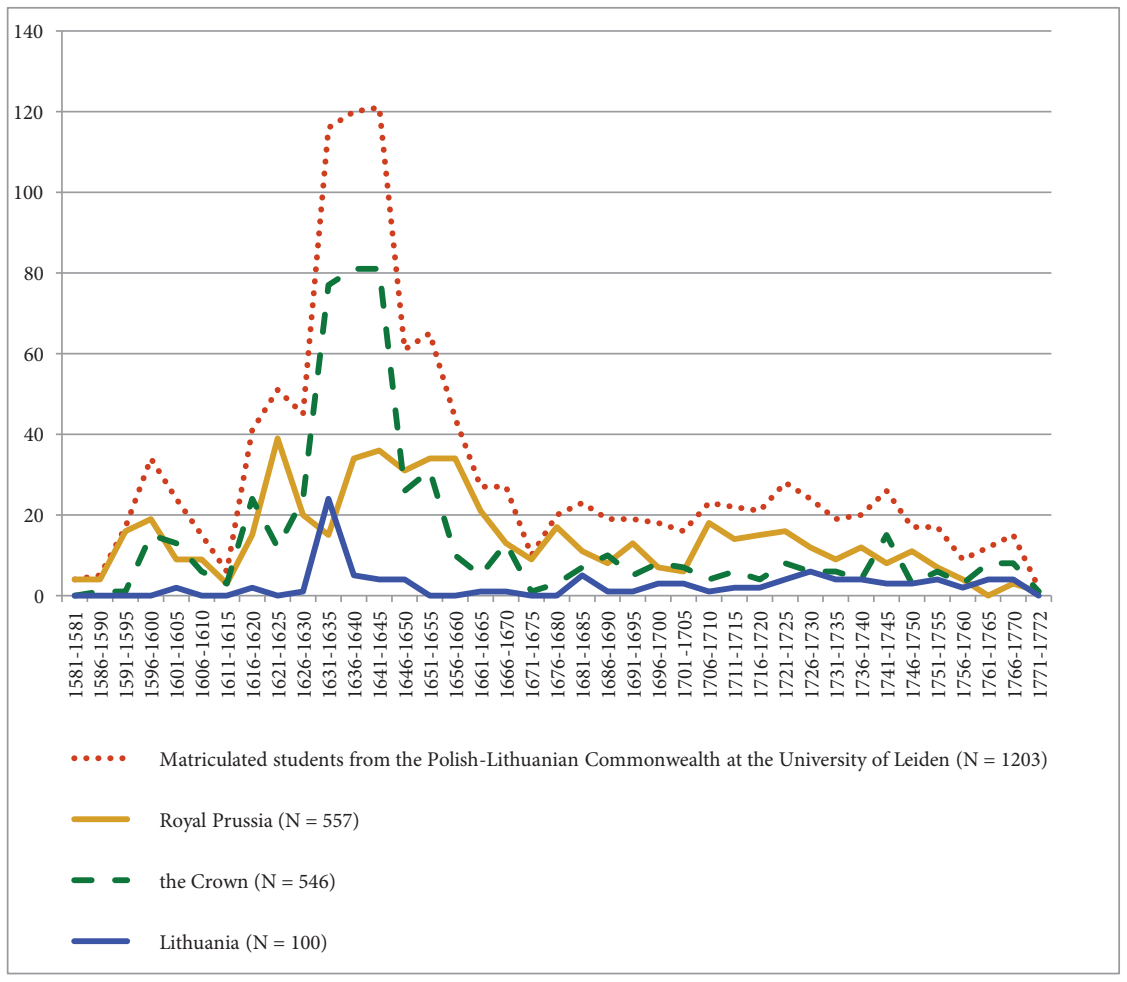

Tab. 1: Students from the Polish-Lithuanian Commonwealth matriculated at the University of Leiden. Source: Pawlak, Studia uniwersyteckie młodzieży, Tab. 25

to move after a short time to Leiden to be trained there by Frans de la Boë Sylvius. In Amsterdam, Rudenick lived under one roof with a renowned anatomist and a professor of medicine Gerard Blaes ${ }^{29}$. Another household member and pupil of that host was Daniel Gödtke from Danzig, who first matriculated at the Medical Faculty in Leiden and just after a few months moved to the capital city of the Dutch Republic to be trained by Blaes and to become a member of his Collegium Privatum ${ }^{30}$.

It should also be remembered that sometimes students from Royal Prussia during the course of their educational stay in the Netherlands were

29 D. van Miert, Humanism in an Age of Science. The Amsterdam Athenaeum in the Golden Age, 1632-1704, (2009), s. 118-119, fn. 11; G. Scherz, Stensen's first dissertation, in: Journal of the History of Medicine and Allied Sciences, 15 (1960), p. 251 \& Fig. 3 (facsimile).

30 Pękacka-Falkowska, Freundtschafft. 


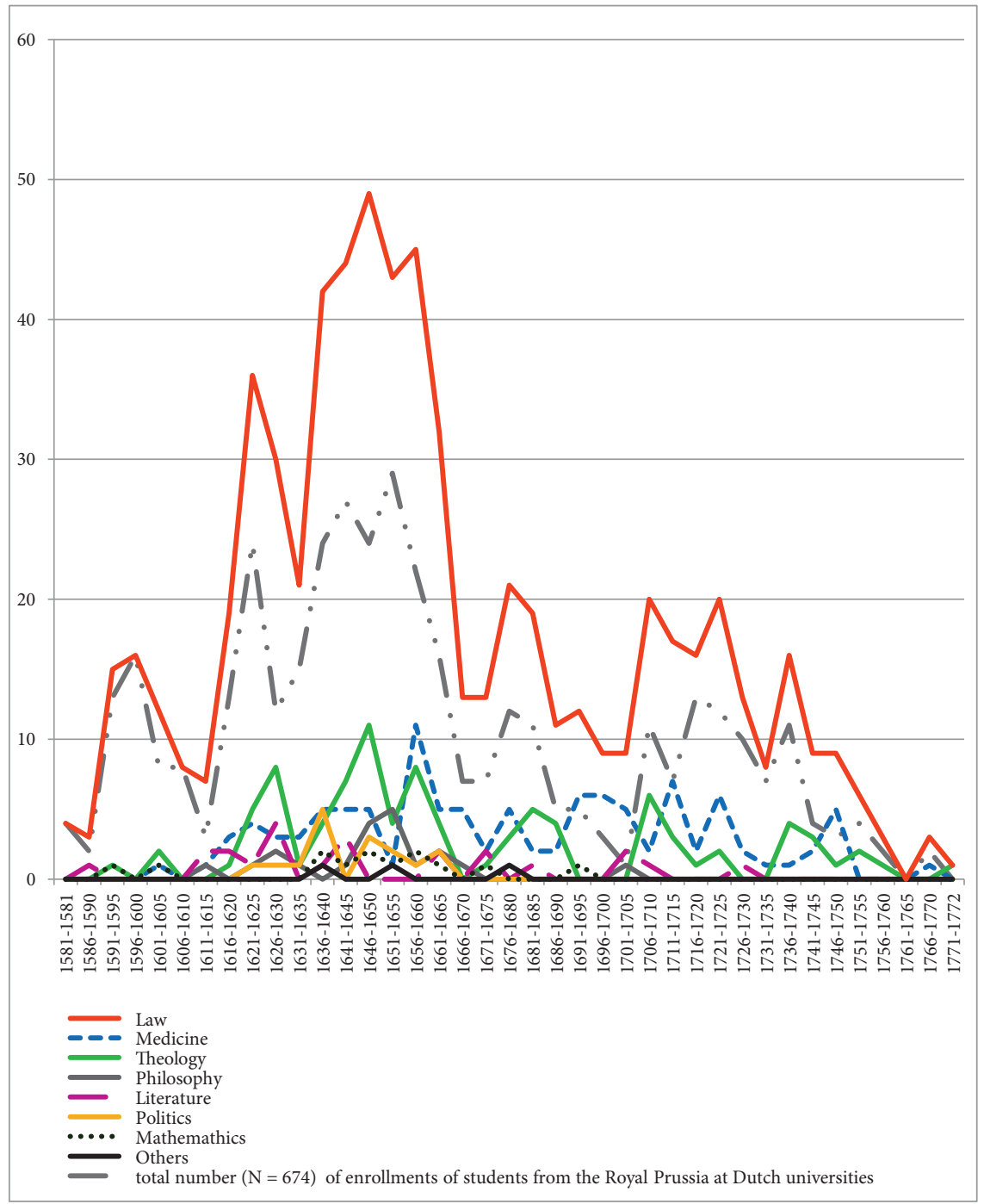

Tab. 2: Students from the Polish-Lithuanian Commonwealth matriculated at all Dutch universities (1578-1772). Source: Pawlak, Studia uniwersyteckie młodzieży, Tab. 29

rapidly changing their field of study. For instance, in 1649 Johannes Specht from Danzig started to study law in Leiden that he continued (from 1651) in Groningen. Again, in 1654 he got back to Leiden, matriculated at the Medical Faculty and graduated in 1657 (Aug $17^{\text {th }}$ ) as a candidate in medicine. Yet, transfers in the opposite direction also could take place. Another 
student from Danzig, Gerhard Martini, started with theology in Franeker. In 1621, he moved to Leiden to the medical faculty, and after just one year he returned to theology, which he continued in Groningen ${ }^{31}$. It is hard to explain in the absence of their ego documents and other relevant historical sources why the students moved across the faculties. We may only guess whether it resulted from their interests or an influence of their professors, peers, colleagues, parents or patrons.

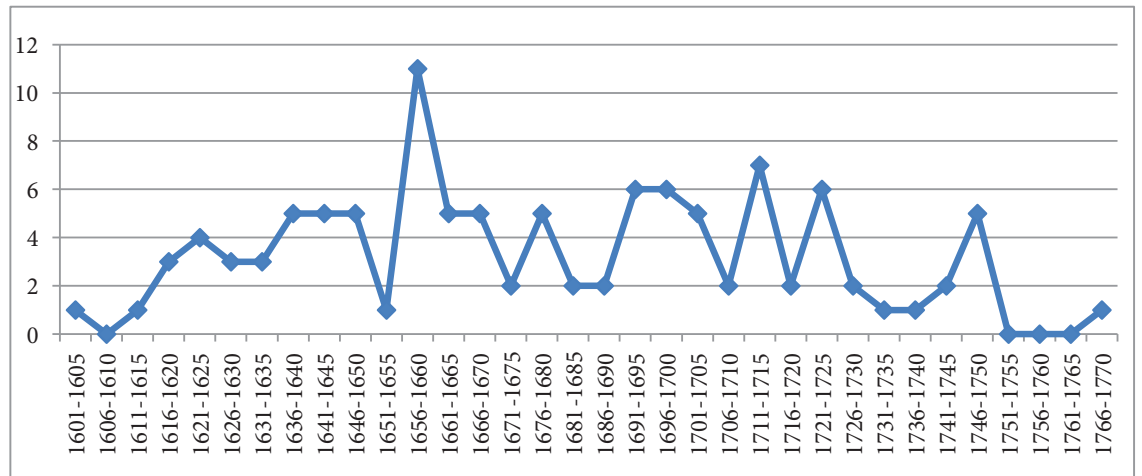

Tab. 3: Number of matriculations of Royal Prussian students $(\mathrm{N}=109)$ at all medical faculties in the Dutch Republic (1578-1770). Source: Pawlak, Studia uniwersyteckie młodzieży, Tab. 29 , col. 2

On the other hand, when it comes to medicine, in the $17^{\text {th }}$ and $18^{\text {th }}$ centuries for many Protestants from the Polish-Lithuanian Commonwealth Academia Lugduno-Batava was the Dutch university of their first choice. Local professors like Johannes van Horne, Otto Heurnius, Frans de la Boë Sylvius, Herman Boerhaave and many others, kept with their commitment to the hands-on approach and practical training of physicians, which actually attracted many young adepts of medicine. From 1604 until 1766, at least 9\% (119) of a global number of students from the Polish-Lithuanian Commonwealth who matriculated at the University of Leiden chose the medical faculty and at least 45 of them graduated there.

The first student from the Polish-Lithuanian Commonwealth to matriculate at the Medical Faculty of Academia Lugduno-Batava was a student

31 Pawlak, Studia uniwersyteckie młodzieży, pp. 153-167. 


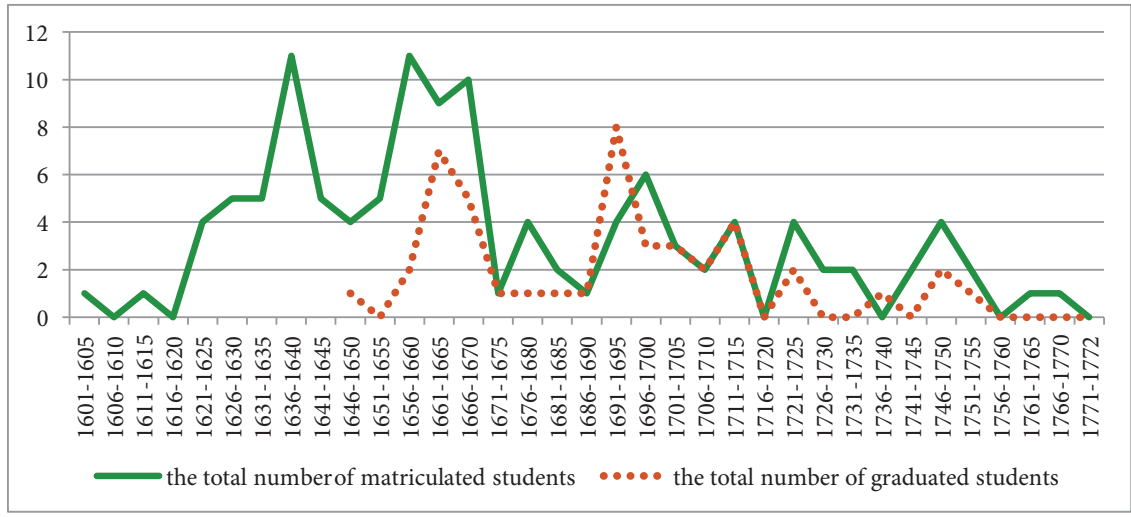

Tab. 4: Matriculations (119) \& graduations (45) of students from the Polish-Lithuanian Commonwealth studying at the Medical Faculty in Leiden (1601-1772). Source: UBL, ASF 7-15, ASF 414-415; Album studiosorum Academiae Lugduno Batavae MDLXXVMDCCCLXXV, ed. G. du Rieu, (1875)

from Danzig, Mattheaus Radetius $(1604)^{32}$, whereas the first graduate (1632) was Adam Freytag from Thorn ${ }^{33}$. Shortly thereafter, Freytag gave up medicine in favour of engineering. Also, John Jonston from Lissa (Leszno) and Daniel Zwicker from Elbing, who graduated respectively in 1634 and 1639 , abandoned (at least partially) medicine. The former one, a universal scholar, took first and foremost to natural history, although he was active as a Stadtphycisus in Lissa ${ }^{34}$. The latter one, in turn, became a renowned Unitarian theologian ${ }^{35}$. Thus, it may be assumed that the first graduate (1650) of the Medical Faculty in Leiden who originated from the Polish-Lithuanian Commonwealth and actually devoted himself completely to ars medica was Simon Schultz from Thorn. In October 1651, he was to become a city physician (Stadtphysicus) in his native town ${ }^{36}$.

32 Album studiosorum Academiae Lugduno Batavae MDLXXV-MDCCCLXXV: accedunt nomina curatorum et professorum per eadem secula, ed. G. du Rieu, (1875), p. 75.

33 A. Freytag, Dispvtatio Medica inavgvralis de Apoplexia: quam cum bono deo ex avthoritate [...] preside Petri Cvnaei [...] Academiae Lugdunensis Rectoris [...] pro Gradu Doctoratus summis in Arte Medica [...], (1632).

34 T. Bilikiewicz, Jan Jonston (1603-1675). Żywot i działalność lekarska, (1931).

35 P. G. Bietenholz, Daniel Zwicker (1612-1678). Peace, Tolerance and God the One and Only, (1997).

36 K. G. Prätorius, J. E. Wernicke, Topographisch-historisch-statistische Beschreibung 
As stated before, the vast majority of medical students from the Polish-Lithuanian Commonwealth who studied in Leiden, originated from the largest cities of Royal Prussia. They were primarily Lutherans. Among 91 students from Polish Prussia, 68 were born in Danzig, 6 in Elbing, 4 in Marienburg (Malbork), and only one in Graudenz. The rest described themselves simply as 'Polono-Borussus' and did not indicate their birthplace in the Album Studiosorum. Students that came from Greater Poland were born in Lissa (5) and Fraustadt (Wschowa) (1) and were Czech and Polish Brethrens. Those from Lithuania originated from Vilna (Wilno) (3) and were Calvinists. Yet, also those who described themselves simply as Poles (Polonus) (18) were religious dissidents like, for instance, the Socinian Christophorus Crell Spinowski and the aforementioned John Jonston, who was a Calvinist. Only one enrolled medical student failed to provide information about the place of his birth. This was Johann Philipp Breyne, a son of the renowned Danzig botanist Jacob Breyne whose family lived in Amsterdam $^{37}$.

A similar remark applies to the graduates of the Medical Faculty at the University of Leiden. The majority of them - 37 out of 45 - were Lutherans from Royal Prussia ${ }^{38}$.

None of the Leiden medical students and alumni who originated from the Polish-Lithuanian Commonwealth seems to have been a Roman Catholic. Surely, Catholic nobles on their grand tours matriculated (often with their servants and tutors) at the Academia Lugduno-Batava, yet they were interested rather in history and politics, familiarizing themselves with foreign 'curiosities' and making acquaintance with famous, powerful, wealthy men etc., rather than studying medicine. They also attended fencing classes and visited numerous sights of interest, like the anatomical theatre and the polders with windmills. Perhaps some of them participated also in collegia privatissima held by professors of history and $\operatorname{arts}^{39}$. Yet, the great majority of them were simply 'tourists', like Marek and Jan Sobieski, the future Polish

der Stadt Thorn und ihres Gebietes: die Vorzeit und Gegenwart umfassend, die Vorzeit und Gegenwart umfassend, (1832), p. 389.

37 BL, Sloane Ms 3321, fols. 138-139; Sloane Ms 4039, fols. 369-370.

38 See Appendix.

39 A. Kucharski, Theatrum peregrinandi. Poznawcze aspekty staropolskich podróży w epoce późnego baroku, (2013), pp. 301-302, 381-383. 
king, completely disinterested in becoming an alumnus ${ }^{40}$. However, this also applied to highly born dissenters from other countries who 'hie [in Leiden] pro forma studiren ${ }^{31}$.

Medical students from the Polish-Lithuanian Commonwealth who decided to study in Leiden could complete their academic medical training in two, respectively three years ${ }^{42}$. The grade of doctor of philosophy and medicine earned at this renowned academy guaranteed them not only a medical career in their homeland, but also a career in the municipal administration and educational institutions. More than half of the graduates of the Medical Faculty at the University of Leiden became Stadt-Physici and other officials; a few of them also became professors of medicine at local academic gymnasiums ${ }^{43}$. It is not surprising then that medical students from the Polish-Lithuanian Commonwealth keenly attended public classes and concurrently took also private (typically paid for) instructions at professors' homes ${ }^{44}$. Those who wanted to become doctors of philosophy and medicine also held public practice disputations (exerciti gratia) that formed an important part of their curriculum. In that way, adepts gained additional learning experience and new practical, e.g. public speaking and oratorical, skills.

Students who decided to graduate from the Medical Faculty of Academia Lugduno-Batava, earning a degree of Doctor of Philosophy and Medicine, were obliged to take a two-step examination first. On the first day, a young man, usually in his late twenties or early thirties, had to explain in the afternoon two selected aphorisms of Hippocrates that had been communicated to him early in the morning at 8 a.m. (see Appendix). On the following day, in turn, he was obliged to explain a case-history of a patient and to suggest a detailed treatment. Afterwards, in a very short time, he was entitled to have the inaugural thesis printed and to request a date for the graduation ceremony. At the graduation ceremony, in front of his fellow students, colleagues, professors, university authorities and other people the

\footnotetext{
${ }^{40}$ K. Targosz, Jana Sobieskiego nauki i peregrynacje, (1985), pp. 147-150.

41 BPG, Ms D.a.85, vol. II. § 77.

42 See Appendix.

43 Pawlak, Studia uniwersyteckie młodzieży, pp. 168-182; Archiwum Państwowe w Gdańsku, 300,R/ H,q2; 300,42/258.

44 Pękacka-Falkowska, Wokót kolekcji przyrodniczych, pp. 58-60.
} 
candidate defended his dissertation pro gradu that he authored ${ }^{45}$ and usually a few additional short theses, called 'corollaria'. The advising professor acted here as a 'promotor'; there was no praeses, or 'presider' (see Appendix). The public disputation lasted a little longer than one hour. Shortly thereafter, the candidate received his doctor's diploma and took an oath, thus becoming a doctor ${ }^{46}$.

However, public promotions in Leiden were very expensive with a fee around 70-80 guilders or even more in some cases (not to speak about the costs of feasting for the professors and colleagues from the faculty ${ }^{47}$ );

45 Prögler, English Students at Leiden University, 1575-1650, pp. 104-105.

${ }^{46} \mathrm{H}$. Beukers, Clinical teaching in Leiden from its beginnings until the end of the $18^{\text {th }} \mathrm{c}$., in: Clinical Teaching, Past and Present, Clio Medica, 21 (1987-1988), pp. 139-152.

47 The aforementioned Ch. G. Fischer described in his diary two medical graduations in 1728. These are the most extensive descriptions of such ceremonies next to the report by Albrecht von Haller who in his diary gave an account of a graduation ceremony from 1725 (G. A. Lindeboom, Haller in Holland: het dagboek van Albrecht von Haller van zijn verblijf in Holland (1725-1727), (1979), pp. 49-50): “§. 61. D. 23. Febr. [1728] war eine Doctor-Promotion, in Medica Facultate. Der Candidatus hieß: Adrianus van Royen, ein geschieckter Mensch, von etl. 20. Jahren, aus einer hiesigen vornehmen Famille. [...] Boerhaven will dem jungen Menschen wohl, und hat eine einige Tochter, die großtes Geld dermahleins zu hoffen. Nach der Promotion gehet der neue Doctor nach Franckreich, die Botaniqve zu excoliren. Hieraus machen einige des Prognosticon, daß dieser von Royen dermahl eins Boerhaven, wo nicht werde adjuncjiret, gewiß nach seinem Tode succediren werde: Obgleich D. Albinus, zur Professione Botanices große Neigung zeiget. Die Disputatio inauguralis, de Anatome, et Oeconomia Plantarum, war dem Hrn. Boerhaven, mit einer schönen Latinischen Elegie dediciret, die Ausführung des gedachten Arguments, ist sehr wohl gerathen. Was bißher von Malpighio, Grewio, und andern, mir verdrüßlicher Weitläuffigkeit, und, ohne Ordnung, von dieser Materie vorgetragen, ist hin mit einem deutlichen, und fleißenden Styl, in ein anatomisch Physiologisches Systema zusammen gezogen, woran ich nichts desiderire, alß, daß nicht die Autores gehörig sind allegiret worden, aus deren Erfahrungen der Autor seine Säze gemachet. Mir komt aber diese Arbeit alß ein Grund-Riß eines größen Wercks vor, woran der Autor zu arbeiten Lust bezeiget. Der Actus disputatorius, gieng umb 10. Uhr, Morgens, im großen Auditorio an. Zu Anfang war Niemand, dem Hr. Boerhaven, alß Promotor, zugegen. Nachdem der Doctorandus von der untern Cathedra mit bloßem Haupt und kurzen Worten, libertatem disputandi gebethen; So meldete sich der erste Opponens auf der Banck, vor dem Catheder, bath auch, mit 2. oder 3. Worten Erlaubniß, zu reden, vom Promotore, und proponirte gleich das Argument wieder die allegirten Worte. Wem einmahl darauf geantwortet worden, schritt der Opponens zu einem andern Argument. In solcher Arth opponirten in einer Stunde 3. Studiosi, und ein Candidatus Medicinae, alle mit entblößtem, und endlich, ein junger Doctor, mit gedecktem Haupt, /: weil Promoti das Jus pilei, auch so gar, in Foro litigioso coram Magistratu haben :/ Mittein im Argument schlug die Uhr 11 worauf, da es der Pedell vor dem Catheder meldete, der Opponens gleich aufhörte; der Respondens 
therefore a number of not well-off students from the Polish-Lithuanian Commonwealth, like among others the aforementioned Daniel Gödtke, having completed their medical education at Academia Lugduno-Batava matriculated at the university of Harderwijk, and in two or three days graduated there ${ }^{48}$.

What were the "cognitive" gains of these medical alumni from Polish Prussia who (among others) studied in the Netherlands and earned their grades at the University of Leiden? To answer this question it would seem sufficient to use two selected examples. In the case of an alumnus from Thorn, Simon Schultz, who studied medicine supervised by Adolph Vorstius, I will briefly present his literary production. In the case of Christoph

dankte darauf, mit wenigen und gemeinen Worten, denen Profesoribus, pro praesentiu., dem Promotori, pro libertate concessu disputandi, denen vornehmen Hospitibus, pro praesentiu., und dem Auditorio, und den Opponenten, pro attentione et oppositione. Unter dem Disputiren, welches so still und leise fortgesetzet ward, daß man in der $3^{\text {ten }}$ Banck vor der Catheder fast nichts hören konnte, wartete der Pedell vor dem Auditorio, und so offt ein Professor in seinem Talar ankahm, gieng er biß am die die Banck vorher, mit seinem großten klingenden Sorgter. Nun halte diese Pedell keinen schwarzen Habit an, sondern er war nur gewöhnlich licht gemäntelt. Nach der Disputation giengen alle Professores nach einander, und endlich auch der Doctorandus hinauf in die Promotions-Stübe, allwo über seine Capacite geurtheilet die vota colligirt, das Promotions-Geld gezahlet, und, der Titel des Doctoris dagegen ertheilet wird" (BPG, Ms D.a.85, vol. II, fols. 86-88). It is also instructive how Fischer described one of the graduations in the Law Faculty and the ceremonial evening dinner, which followed: "§. 79. D. 11. 12. 13. Martii, waren auf der Academie 3. Doctor-Promotiones; die beyden ersten, in Medicina, publice: die $3^{\text {te }}$ in Jure, sub Camino. Der Doctorandus war Mons. Guil. Sautzn, ein reicher Gast, von Amsterdam, aus vornehmen Famille [...]. Selbiger ließ auf die Promotion viel gehen. Nach der Promotion, kahm er bey unsern Wirth, in den Tempel Salomonis /: da wir, wegen Commodite zu speisen angefangen :/ zu Tisch, und war, von der Fuß-Sohlen, biß an den Halß, mit breiten Silber beschlagen: die Kleidung importirte mehr, alß manches Doctoris ganzes Capitel. Unter der Mahlzeit, beachte der Pedell die Bulle, mit dem anhangenden großen Siegel, woran sich der Hr. Doctor über Tisch belustigte: Seine guten Freunde, und Tisch-Compagnons unterdeßen nicht etwas mit Ihm zu scherzen unterfiengen. Gegen die Nacht, umb 9. Uhr, war der Doctor-Schmauß angesezet, auf welchen unser Wirth die raresten Delicateßen zurichtete. Hie war wieder eine höltzerne verguldete Pastet vor 30. Gr. Holl. und, was nur neues und rares von Essen, an Wilpret, und Braten, zu erdencken war. Eine junge Gans bezahlete der Koch mit 2. Ducaton, jeden Phasan, 1. Ducaton. 1. Hasen, 6. Gr. Holl. Die Zurichtung war auf Personen wovor der Koch allein bekommen” (ibid., fols. 129-130).

48 UBL, ASF-358, passim; D. Onnekink, G. Rommelse, The Dutch in the Early Modern World: A History of a Global Power, (2019), pp. 166, 169; Pękacka-Falkowska, Freundtschafft. 
Gottwald from Danzig, a supervisee of Frans de la Boë Sylvius, I will focus on his iconographic legacy.

As one may assume, the majority of graduates from the semiperipheries such as the Polish-Lithuanian Commonwealth eagerly recalled the study time in Leiden in their adult life. The city physician of Thorn Simon Schultz (1622-1679) is the foremost example of a professional from the Polish Prussia who re-worked and described his past experiences in the Dutch Republic. During his study years under Vorstius, a great physician and a botanist, Schultz closely followed and recorded numerous behaviours of his fellow students, teachers and ordinary men. These observations gave later rise to the long series of his medical observations - observationes published in 'Miscellanea Curiosa', the learned journal of the Academy of the Curious as to Nature (Academia Naturae Curiosorum). Descriptions of peculiar dining behaviours of his table-mates, numerous impressions from anatomical demonstrations or city walks were forged by Schultz into short, and instructive medical entries.

In 1649, one of Schultz's fellow students, an anonymous Scotsman, young, healthy, yet a little bit pale and with swollen eyelids, as a citizen of Thorn described him over the years, regularly consumed spiders that inhabited his place. Further eyewitnesses of that uncommon dining behavior of Schultz's roommate were two other medical students, Tobias Schultz from Thorn and Nicolaus Witte from Riga, who regularly dined with them. Witte was to become in 1652 a physicus secundus in his native city ${ }^{49}$; thus, he was a credible witness of high social rank who could provide a gentleman's testimony of this bizarre behaviour described by Schultz in $1671^{50}$.

Schultz and other alumni also eagerly recalled their practical medical training, referring in particular to anatomy classes. Hence, in one of his further observationes, Schultz described that in 1648 he took part in an autopsy of a young woman with an abdominal tumour. The corpse was cut open by a hospital surgeon in the presence of J. Walaeus, a professor of

49 A. Tering, Riga Municipal Physician Nicolaus Witte von Lilienau (1618-1688): His Medical Views at the Crossroads of Tradition and Changes in Medical Teaching during his Student Years at Dutch Universities in the 1640s, in: Acta Baltica Historiae et Philosophiae Scientiarum, 2 (2014).

50 S. Schultz, Obs. X: Idiosyncrasia Naturalis, Aranearum Comestio innoxia, in: Miscellanea Curiosa, sive Ephemeridum Medico-Physicarum Germanicarum Academiae Naturae Curiosorum, 2 (1671), p. 29. 
medicine and the supervisor of the St. Caeciliagasthuis, and of numerous students matriculated at the Medical Faculty. The dissector cut the enormous tumour off the deceased lady's uterus and showed it to the audience, whereas the teacher provided a comprehensive commentary $y^{51}$. During his professional career as a city physician in Thorn Schultz keenly focused on such pathologies and most likely communicated them not only to the learned readership but also to the students of Atheneum Thorunense (who were interested in medicine) along with local barber-surgeons.

Another dissection, yet, public this time, was performed in the presence of Schultz on December $30^{\text {th }}, 1649$. For the nonce, it was a corpse of an 18year-old-male beggar suffering from epilepsy who had died in St. Cecilia's hospital two days before. The young man's body was cut open in the anatomical theatre crowded by scholars and laymen. The dissector was Doctor Adrian Falkenburg, a public lecturer in anatomy and surgery, who searched in presence of the viewers for the 'true cause' of the young man's death ${ }^{52}$. Falkenburg's (and other Leiden teachers') dissecting techniques might have been adopted by Schultz who afterwards could have introduced them in Thorn. At this point, it should be emphasized that another physician from Royal Prussia Georg Seger stated several times that he exclusively relied on dissection methods introduced by Thomas Bartholin, Seger's beloved teacher during his study stay in Copenhagen ${ }^{53}$.

Last but not least, medical students from Royal Prussia like those from Thorn also had numerous ethnographical insights referring to popular medicine. For instance, Schultz described a specific building stone from Bentheim used by the dwellers of Amsterdam and Leiden as a remedy against kidney stones ${ }^{54}$. It is very likely that Doctor Schultz used similar

51 S. Schultz, Obs. LX: Infimus Venter Totus Scirrhosus, in: Miscellanea Curiosa, sive Ephemeridum Medico-Physicarum Germanicarum Academiae Naturae Curiosorum, 2 (1671), p. 118.

52 S. Schultz, Obs. LXII: Corporis Epilepsia Extincti Anatomica Administratio, in: Miscellanea Curiosa, sive Ephemeridum Medico-Physicarum Germanicarum Academiae Naturae Curiosorum, 2 (1671), p. 120.

53 G. Seger, Obs. XXXII: De Anatome Solemni Furis Quinquagenarii, in: Miscellanea Curiosa Medico-Physica Academiae Naturae Curiosorum, 8 (1677), pp. 59-62; Pękacka-Falkowska, Między Gdańskiem a Toruniem.

54 S. Schultz, Obs. LXIII: Remedium plebejorum ad calculum, in: Miscellanea Curiosa, sive Ephemeridum Medico-Physicarum Germanicarum Academiae Naturae Curiosorum, 2 (1671), p. 121. 
'earthy' simple medicines in his daily practice in Thorn. Suffice it to recall that this type of remedies was still very popular at the beginning of the $18^{\text {th }}$ century ${ }^{55}$.

In Leiden, the young citizen of Thorn also found a piece of evidence for maternal imagination theory. In 'Miscellanea Curiosa' he accurately described a curious case of a heavily pregnant woman of low social rank who while passing the Langebrug in Leiden, suddenly felt fatigued and sat down in front of the entrance door to a brick house that belonged to a man with club feet and deformed clenched hands. When she unexpectedly saw one of his palms, she was so terrified that she nearly fainted. Thus, the good man comforted her and strengthened her spirits with a glass of French wine. Shortly thereafter, she returned home and told the story to her husband. In a very short time, the woman gave birth to a child with limb deformities, exactly the same as she had seen earlier. When Schultz after his educational trip that he continued in England and the Spanish Netherland was getting back through the Dutch Republic to his native town, he was informed that the child was perfectly healthy, only his extremities remained unchanged ${ }^{56}$. For an alumnus, this was definitive proof that the power of maternal imagination may be as great as to deform even a fully-formed 9-month foetus.

As mentioned before, before graduating, students also took part in various disputations for practice: both public and private ones. In 1648, two years before graduating, under Vorstius as presider Schultz explained the causes, diagnosis, prognosis, and treatment of Polish pile (plica Polonica) ${ }^{57}$. Despite the fact that it was Vorstius who served as a 'presider', it is most likely that it was Schultz, the respondent, who had chosen the topic on his own. Nearly 30 years later he re-edited the disputation and published its new extended version in 'Miscellanea Curiosa'. The long, erudite passages

55 BL, Add Ms 4435, fols. 176-177.

56 S. Schultz, Obs. LXI: Phantasia Et Terror In Gravida Foetui Valde Noxia, in: Miscellanea Curiosa, sive Ephemeridum Medico-Physicarum Germanicarum Academiae Naturae Curiosorum, 2 (1671), pp. 118-120.

57 [S. Schultz], Disputatio medica de plica Polonica. Quam auspice Deo ter opt. max. Praesid Spectabili, Clarissimo et Experentissimo Viro, Dn. Adolfo Vorstio Med. D. Ejusdemque \& Botanices P.P. ac Horti Academici Praefecto. In florentissima Lugduno-Batava Academia public examine subjicit Simon Schultz, Thorunio-Prussus a.d.13 Julii, Loco horisque solitis (1648); Książnica Kopernikańska w Toruniu, call number K. 6 nlb. $\left(4^{\circ}\right)$. 
from the original Leiden disputation were enriched this time by his numerous observations from the Kingdom of Poland (Fig. 1) ${ }^{58}$. Such a practice of republishing was reserved for authors ${ }^{59}$. It suffices to recall that Frans de la Boë Sylvius republished the disputation exerciti gratia by Christoph Gottwald $^{60}$. However, also professors of numerous illustrious schools and universities Europe over did the same thing. For instance, Georg Seger republished in Danzig natural history and medical disputes he presided in Thorn in the years $1668-1673^{61}$.

However, observations made by the medical students from the Polish Prussia during their educational stays at the University of Leiden were forged not only into textual testimonies. There is also a vast iconographic legacy of their medical stays. And here the most illustrative example is Christoph Gottwald (1636-1700) along with his etchings.

Doctor Gottwald was not only a city physician in Danzig and a collector, whose vast 'museum' after his son's death was transferred to the Kunstkamera of Tsar Peter the Great ${ }^{62}$. He was also an anatomist, an ivory-turner and an accomplished engraver. In the late 1650s, he started his medical training in Strasbourg, and shortly thereafter, attracted by the fame of the Medical Faculty in Leiden, moved to the Netherlands.

When Gottwald studied in the Dutch Republic in the early 1660s, many dissections and experiments went on there. On the one hand, in Leiden the dissections took place in the anatomical theatre; on the other hand, they were performed in the St. Caeciliagasthuis and possibly also in private

58 S. Schultz, Obs. CXXXVIII: De Plica Explicata, in: Miscellanea Curiosa Medico-Physica Academiae Naturae Curiosorum, Sive Ephemeridum Medico-Physicarum Germanicarum, 6/7 (1675/1676), pp. 187-202.

59 See, for instance, Van Miert, Humanism in an Age of Science, pp. 153-156.

60 Disputatio VIII. De vasis lymphaticis ac lympha. Resp. Christophoro Gottwald Dantisco-Prusso, 19. Mart. 1661, in: F. De Le Boe Sylvii, Medicinae Practicae in Academia Lugduno-Batava Professoris. Disputationum Medicarum Decas. Primarias corporis humani functiones naturales. nec non febrium naturam, ex anatomicis. practicis etc.; chimicis experimentis deductas. complectens: Omnibus ad Leidense exemplar fideliter conformatis, (1674), pp. 127-160.

61 G. Segerus, Synopsis Physicae Antiquo-Novae, edition secunda, (1677); Pekacka-Falkowska, Między Gdańskiem a Toruniem.

62 D. Novgorodowa, Musaeum Gottwaldianum i jego losy w Rosji, in: Klio. Czasopismo poświęcone dziejom Polski i powszechnym, 46 (2018), pp. 109-137. 
houses of the professors ${ }^{63}$. During the two-and-a-half-year stay at Academia Lugduno-Batava Gottwald attended at least 8 dissections both in Nosocomio and in the public anatomical theatre. The dissections in the Caeciliagasthuis were mostly performed by his beloved teacher Sylvius, on whose request the young citizen of Danzig took many anatomical sketches as he did not mind the odour of the dissection chamber. After Gottwald's return to his native city, the drawings formed the basis for his copper-plates and his 'paper museum?

Indeed, a few of Gottwald's anatomical copperplates display the autopsies the young Royal Prussian took part in during his stay in the Netherlands. For example, along with Sylvius he searched for a submandibular gland (Fig. 2), a thoracic duct and salivary ducts. In Leiden, he also researched intestines and mesentery, observed gangliocytoma of the cerebellum and liver spots (which were called moles). Moreover, Gottwald - both in Leiden and in Amsterdam - witnessed numerous physiological experiments on animals ${ }^{64}$, and also saw, in 1661, a sea-monster from Katwijk found on November $12^{\text {th }}$ and dissected shortly thereafter by Johannes van Horne (Fig. 3-5) ${ }^{65}$.

In Danzig, the physician continued his anatomical studies in a Sylvian manner, conducting anatomical and zootomical research in a private anatomical room in his house (Fig. 6). He also started to amass a collection, the Musaeum Gottwaldianum. Some of the exhibits on display were acquired during his study years in the Dutch Republic; some of them could even have been gifts made by his teacher Sylvius. Gottwald's rapidly growing interest in minerals and lithiasis also resulted from Sylvius' iatrochemical teachings ${ }^{66}$.

As mentioned before, when Gottwald studied in Leiden, much experimenting went on there in order to investigate the nature of newly discovered physiological phenomena ${ }^{67}$. As the Dutch historian of medicine

\footnotetext{
63 Huisman, The Finger of God, passim.

64 Pekacka-Falkowska, Instrumenty.

65 Zeemonster gevangen tussen Scheveningen en Katwijk, 1661 Een Wonderlyck Zee-Monster te sien, (1661), http://hdl.handle.net/10934/RM0001.COLLECT.370269; Abbildung /// Eines erschrecklichen // Meer=Wunders // So am Ende deß 1661. Jahrs in Holland zwischen Schevelingen und Catwick // auff=See gefangen Worden, (1662), http://sammlungen. ub.uni-frankfurt.de/freytag/urn/urn:nbn:de:hebis:30:2-40429.

66 Pękacka-Falkowska, Wokół kolekcji przyrodniczych.

67 G.A. Lindeboom, Dog and Frog: Physiological Experiments at Leiden during the Sev-
} 
Tim Huisman argued, many of these experiments were performed with the help of syringes and other surgical and anatomical instruments ${ }^{68}$. Coloured fluids were injected into organs in order to determine the course of blood vessels and veins. Similar techniques were used to inject coloured wax and coloured fluids composed of alcohol, different metals, pigments and wax into the veins and vessels of anatomical specimens ${ }^{69}$. Gottwald like other prominent students of Sylvius - Swammerdam, De Graaf, Ruysch etc. - was also well-trained in the use of syringes in anatomical and physiological research. One of his copperplates depicts a syringe - a tube with a piston together with numerous tubes of different shapes (Fig. 7) ${ }^{70}$. Gottwald used it not only in his physiological experiments on dogs and other animals, but also while making anatomical specimens and models, for instance, the one representing his deceased baby son $^{71}$.

$$
*^{*} *
$$

These briefly presented examples of the two alumni of the Medical Faculty of the University of Leiden - Doctors Gottwald and Schultz - may show us what type of knowledge, skills, research interests and artefacts students from Royal Prussia brought back home from their educational journeys, including their study years at the Academia Lugduno-Batava.

enteenth Century, in: Leiden University in the seventeenth century: An exchange of learning, ed. by Th. H. Lunsingh Scheurleer, G.H.M. Posthumus Meyjes, (1975), pp. 279-293.

68 Huisman, The Finger of God, pp. 83-84.

69 F. J. Cole, The history of anatomical injections, in: Studies in the history and metod of science, ed. C. Siger, 2 (1921), pp. 285-323.

70 K. Pękacka-Falkowska, Instrumenty chirurgiczno-anatomiczne i rytownicze gdańskiego lekarza Christopha Gottwalda (1636-1700), in: Klio. Czasopismo poświęcone dziejom Polski i powszechnym, 46 (2018), pp. 157-183.

71 I argue that a wax figure of an infant lying in a glass case, wearing a bonnet and wrapped in a cloth (depicted by Ivan Sokolov as a part of Icones pictee rerum quee in Academice thesaurus in sunt) was created by $\mathrm{Ch}$. Gottwald and is a realistic representation as to colour and form of his dead son, whereas Jozien Driessen has pointed out that "this was not a waxwork model, but a model made from a dry preparation from Peter the Great's collection which he bought from the Amsterdam doctor Frederik Ruysch". See The Paper Museum of the Academy of Sciences in St. Petersburg c. 1725-1760: Introduction and Interpretation, ed. R. Kistemaker, (2005), p. 217 (fn. 4), 221 (n. 0558); G. Kohfeldt, Eine akademische Ferienreise von Rostock bis Königsberg im Jahre 1694, in: Baltische Studien, 9 (1905), p. 22: '14): "Sein sohnchen in wachs posiret als lebendig in glaesernen Sarck”. 
In 2010, Andrew Cunningham wrote, that in the Early Modern period medicine was 'the subject where foreign travel was most valuable, especially when one came to set up a practice at home ${ }^{372}$. The students from the Polish-Lithuanian Commonwealth who were alumni of Dutch academies came back to their homeland really enthusiastic about what they had seen and learnt abroad. Trying to practice the way they had experienced in Leiden, Amsterdam and Harderwijk, writing about their past and current medical involvements, corresponding with their former colleagues and teachers etc. they were transforming the medical cultures of not only Danzig, Thorn, Lissa, or Elbing, but also of the Polish royal court and numerous magnates' courts.

Corrected by Agnieszka Chabros

72 A. Cunningham, The Bartholins, the Platters and Laurentius Gryllus: the peregrinatio medica in the Sixteenth and Seventeenth Centuries, in: Centres of Medical Excellence, p. 4. 


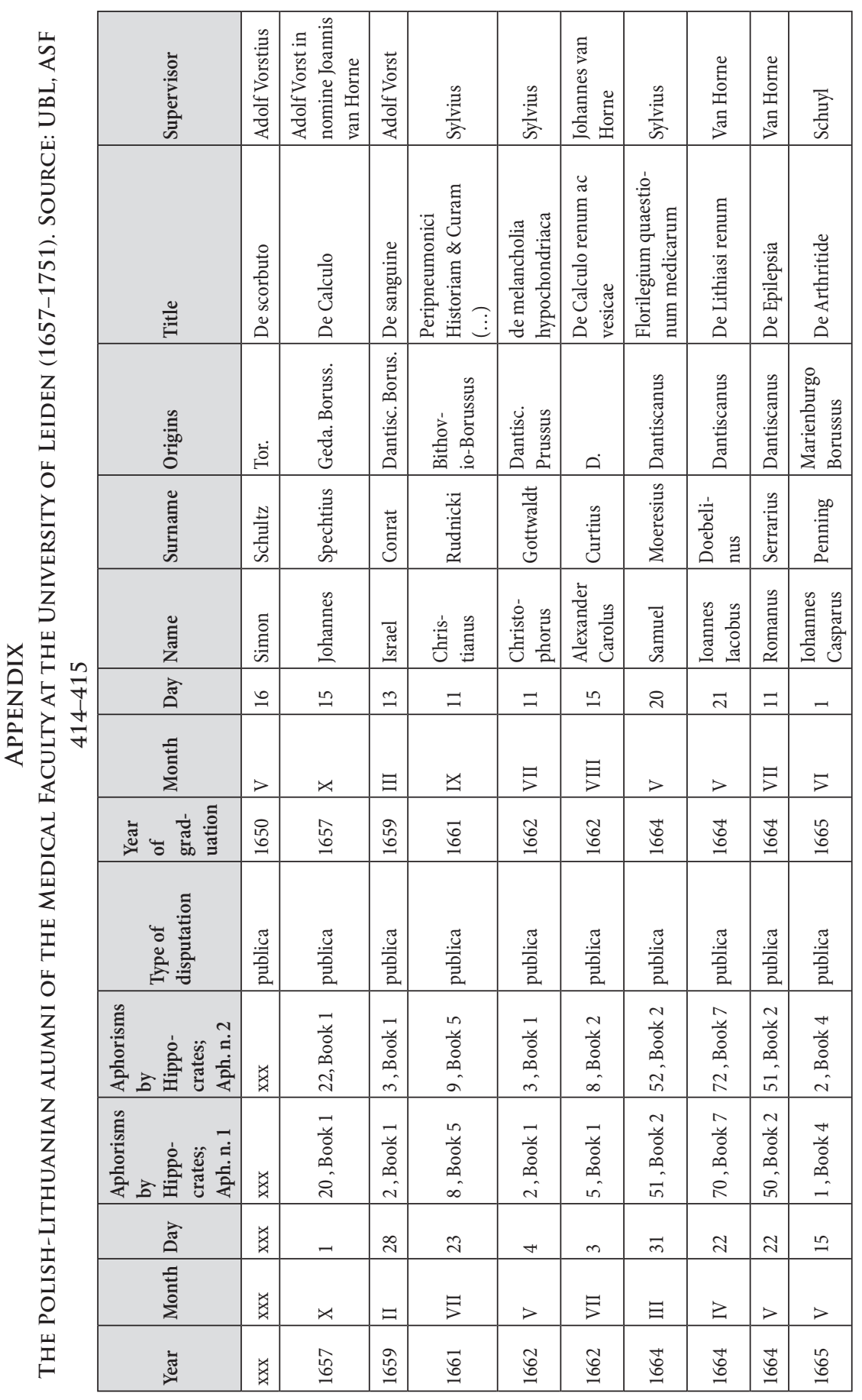




\begin{tabular}{|c|c|c|c|c|c|c|c|c|}
\hline 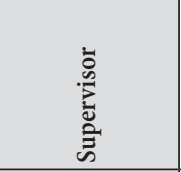 & $x$ & 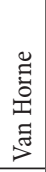 & 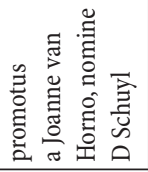 & 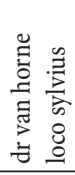 & 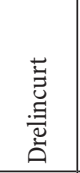 & 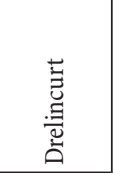 & 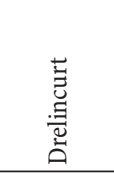 & 泀 \\
\hline$\stackrel{\Xi}{\Xi}$ & 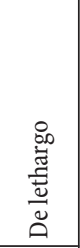 & 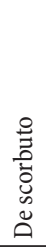 & 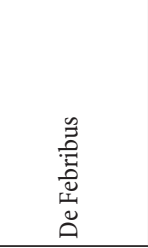 & 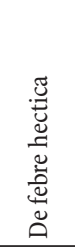 & 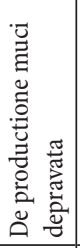 & 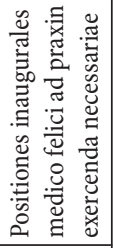 & 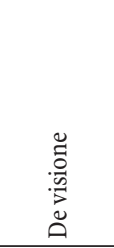 & 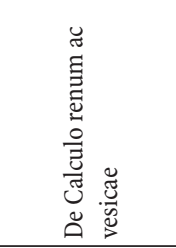 \\
\hline 莺 & 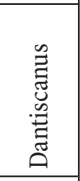 & 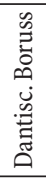 & 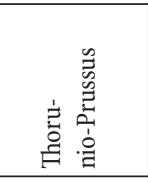 & 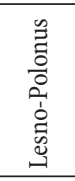 & 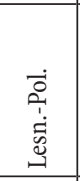 & 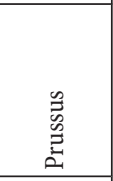 & 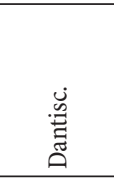 & 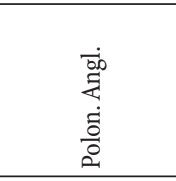 \\
\hline 节 & 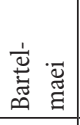 & 节 & $\begin{array}{l}\text { 前 } \\
\text { 㝘 }\end{array}$ & 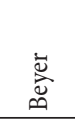 & 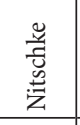 & 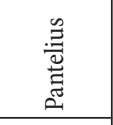 & 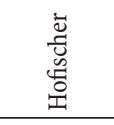 & 章 \\
\hline $\begin{array}{l}\text { छ̆ } \\
\text { Zू }\end{array}$ & 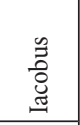 & 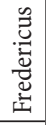 & 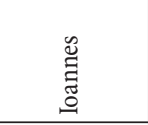 & $\begin{array}{l}\mathscr{\Xi} \\
\stackrel{\Xi}{\Xi} \\
\end{array}$ & 嵒 & $\sum_{0}^{0}$ & 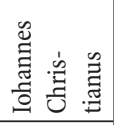 & 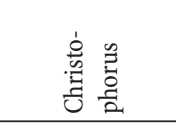 \\
\hline 气ิ & $\vec{\sim}$ & $\hat{\imath}$ & $\stackrel{0}{-1}$ & $\ddot{\sim}$ & 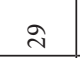 & in & 6 & 6 \\
\hline 竞 & 5 & $Z$ & 5 & $凶$ & $凶$ & $\check{\beth}$ & $=$ & $\xi$ \\
\hline 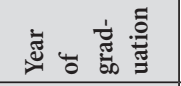 & $\stackrel{\widehat{\theta}}{0}$ & $\underset{\stackrel{0}{0}}{\stackrel{\infty}{0}}$ & $\underset{\stackrel{\infty}{\circ}}{\stackrel{\infty}{0}}$ & $\underset{0}{0}$ & 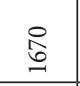 & $\underset{6}{\mathbb{6}}$ & $\underset{0}{\stackrel{\circ}{0}}$ & 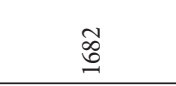 \\
\hline 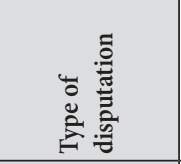 & 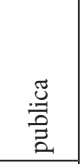 & $\begin{array}{l}\stackrel{\overparen{J}}{7} \\
\vec{\Xi} \\
\end{array}$ & 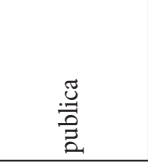 & 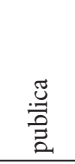 & 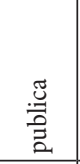 & 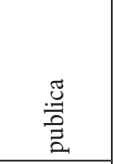 & 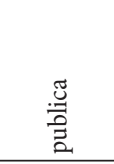 & 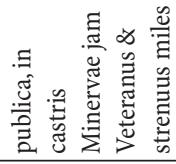 \\
\hline 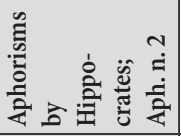 & 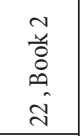 & 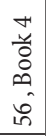 & 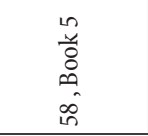 & 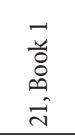 & 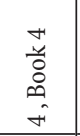 & $\begin{array}{l}\text { in } \\
\text { है } \\
0 \\
\text { กิ } \\
\text { กิ }\end{array}$ & 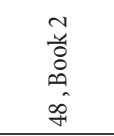 & 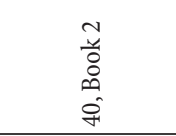 \\
\hline 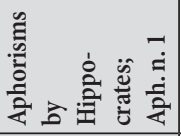 & 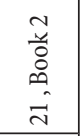 & 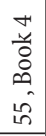 & $\begin{array}{l}\text { in } \\
\text { क्ष } \\
\infty \\
\text { in } \\
\text { in }\end{array}$ & 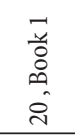 & $\begin{array}{l}\text { Na } \\
\stackrel{0}{0} \\
\infty \\
\text { mे }\end{array}$ & $\begin{array}{l}\text { in } \\
\text { - } \\
\infty \\
\infty \\
\text { ì }\end{array}$ & 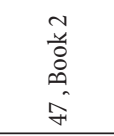 & 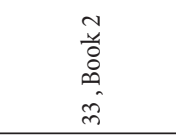 \\
\hline$\widehat{\vec{\Xi}}$ & $ㅇ$ & in & $\hat{\lambda}$ & $\stackrel{\infty}{\sim}$ & $\approx$ & N & $\vec{m}$ & $\ddot{\sim}$ \\
\hline 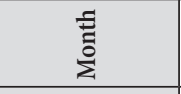 & 5 & $Z$ & $\Xi$ & 5 & 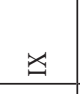 & $>$ & - & 5 \\
\hline 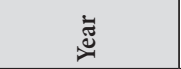 & $\underset{\theta}{0}$ & $\underset{\mathscr{O}}{\infty}$ & $\underset{0}{\infty}$ & $\underset{0}{0}$ & 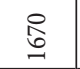 & $\underset{-1}{\mathbb{6}}$ & $\underset{0}{\mathscr{0}}$ & 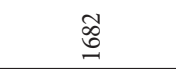 \\
\hline
\end{tabular}




\begin{tabular}{|c|c|c|c|c|c|c|c|c|c|c|c|c|}
\hline 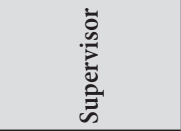 & 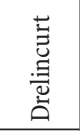 & 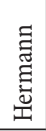 & 节 & $\begin{array}{l}\text { 苛 } \\
\text { 年 }\end{array}$ & 㽦 & 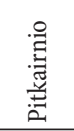 & 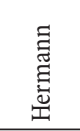 & 节 & 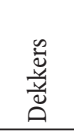 & $\stackrel{\circ}{\stackrel{0}{0}}$ & 岂 & $\begin{array}{l}0 \\
0 \\
\text { ث: } \\
\end{array}$ \\
\hline$\stackrel{\varrho}{\Xi}$ & 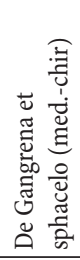 & 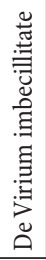 & 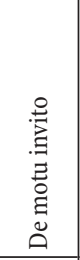 & 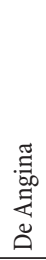 & 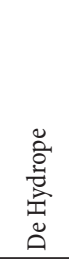 & 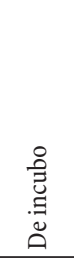 & 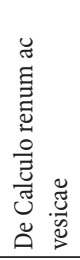 & 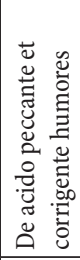 & 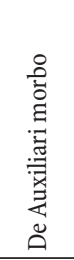 & 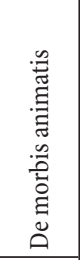 & 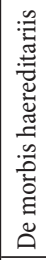 & 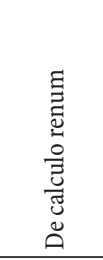 \\
\hline 童 & 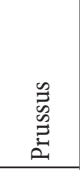 & 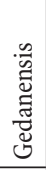 & 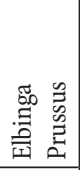 & 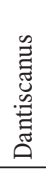 & 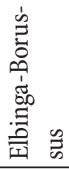 & 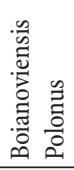 & 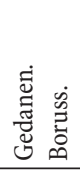 & 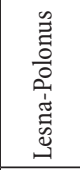 & 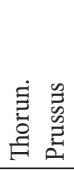 & 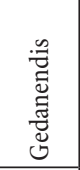 & 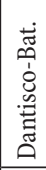 & 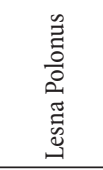 \\
\hline 嶽 & 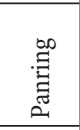 & $\begin{array}{l}\text { ڤ̆ } \\
\text { E }\end{array}$ & 苛 & 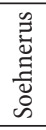 & 空 & 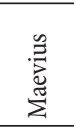 & 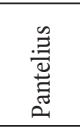 & $\begin{array}{l}\text { 莟 } \\
\text { 去 }\end{array}$ & $\frac{\infty}{\tilde{u}}$ & $\begin{array}{l}\text { 胥 } \\
\text { 吾 } \\
\end{array}$ & 总 & 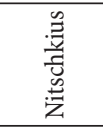 \\
\hline $\begin{array}{l}\text { İ } \\
\text { Z̃ }\end{array}$ & 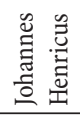 & 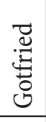 & 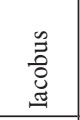 & 莒 & 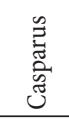 & 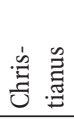 & 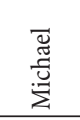 & 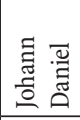 & 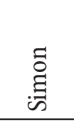 & 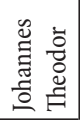 & 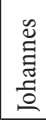 & 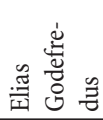 \\
\hline 气̂ & $\stackrel{\sim}{\sim}$ & in & in & $\triangleq$ & $\stackrel{2}{ }$ & 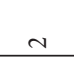 & $m$ & $\stackrel{\infty}{=}$ & iి & 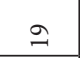 & 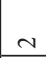 & 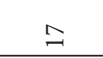 \\
\hline 竞 & 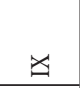 & 目 & $\exists$ & $Z$ & 5 & $x$ & 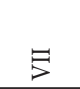 & 5 & $\check{\beth}$ & $x$ & $\nexists$ & $\Xi$ \\
\hline 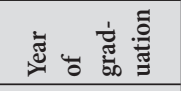 & ఫి & $\vec{\sigma}$ & ప్రి & ప్రి & ప్ & రి & $\tilde{\sigma}$ & 苛 & 능 & ڤั & $\stackrel{0}{0}$ & $\stackrel{8}{1}$ \\
\hline 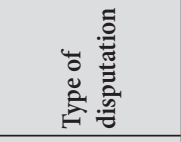 & 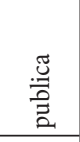 & $\begin{array}{l}\stackrel{\widetilde{Z}}{7} \\
\text { है } \\
\end{array}$ & 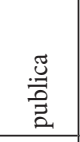 & 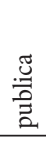 & 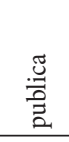 & 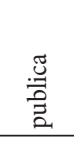 & 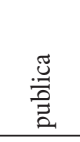 & 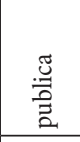 & 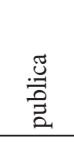 & 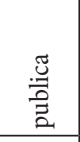 & 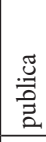 & 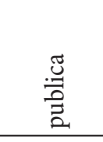 \\
\hline 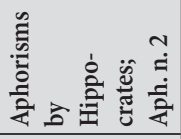 & $\begin{array}{l}0 \\
\text { ¿ै } \\
\stackrel{0}{2} \\
8 \\
8\end{array}$ & 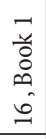 & 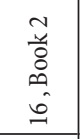 & 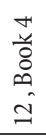 & 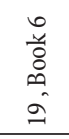 & $\begin{array}{l}m \\
\stackrel{m}{0} \\
\stackrel{0}{0} \\
\text { ते }\end{array}$ & $\begin{array}{l}1 \\
\frac{y}{0} \\
\infty \\
0\end{array}$ & 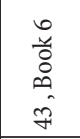 & 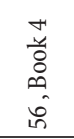 & $\begin{array}{l}\vec{y} \\
\stackrel{\circ}{0} \\
\infty \\
\infty\end{array}$ & $\begin{array}{l}\overrightarrow{7} \\
\vec{y} \\
\infty \\
\infty \\
\infty\end{array}$ & 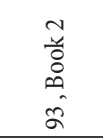 \\
\hline 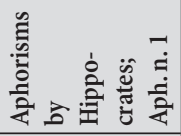 & $\begin{array}{l}0 \\
\text { जै } \\
\circ \\
\text { की } \\
\text { हो }\end{array}$ & $\begin{array}{l}\vec{z} \\
\stackrel{0}{0} \\
\curvearrowleft \\
\text { 으 }\end{array}$ & 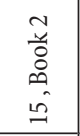 & $\begin{array}{l}\vec{H} \\
\stackrel{4}{0} \\
\stackrel{0}{0} \\
= \\
=\end{array}$ & 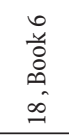 & $\begin{array}{l}m \\
\text { ñ } \\
0 \\
0 \\
\hat{0} \\
\hat{\imath}\end{array}$ & 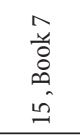 & 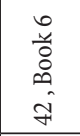 & $\begin{array}{l}4 \\
\text { H } \\
8 \\
0 \\
0 \\
\text { in }\end{array}$ & $\begin{array}{l}\vec{y} \\
\stackrel{2}{0} \\
\stackrel{0}{n} \\
\end{array}$ & $\begin{array}{l}\vec{y} \\
\overrightarrow{0} \\
0 \\
n \\
n\end{array}$ & $\begin{array}{l}\frac{\pi}{0} \\
\text { ¿े } \\
\text { aू }\end{array}$ \\
\hline $\overrightarrow{\mathrm{A}}$ & $\infty$ & $m$ & 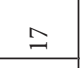 & $\stackrel{\infty}{=}$ & 으 & $\hat{\imath}$ & లి & $\stackrel{\sim}{\sim}$ & $\stackrel{\sim}{2}$ & $a$ & 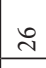 & $a$ \\
\hline 莣 & 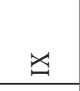 & $\Xi$ & $\varpi$ & $\Xi$ & 5 & $\unlhd$ & - & $>$ & $\unlhd$ & $x$ & $x$ & 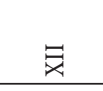 \\
\hline Ð્స & \&్రి & ప్ర & ప్ & ర్ర్త & ర్ & శ్ & ్ֶర్- & 冚 & $\stackrel{2}{\sigma}$ & ఫ̊ & ఫ̊ & 흠 \\
\hline
\end{tabular}




\begin{tabular}{|c|c|c|c|c|c|c|c|c|c|}
\hline 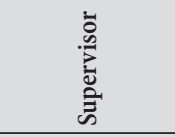 & 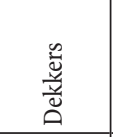 & 春 & 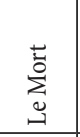 & 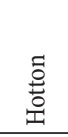 & 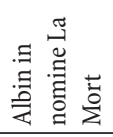 & 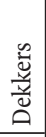 & $\frac{8}{0}$ & 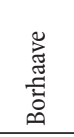 & 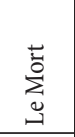 \\
\hline$\stackrel{\varrho}{\Xi}$ & 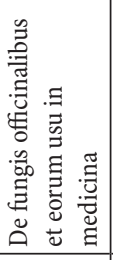 & 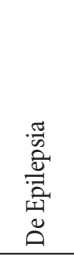 & 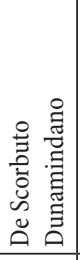 & 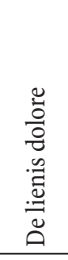 & 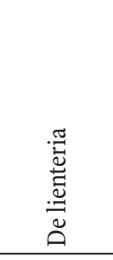 & 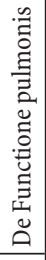 & 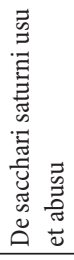 & 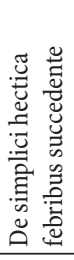 & 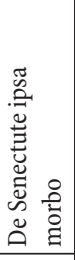 \\
\hline 窇 & 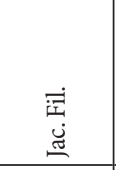 & 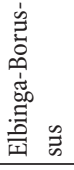 & 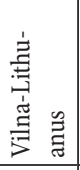 & 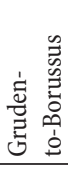 & 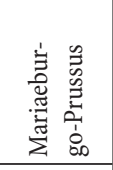 & 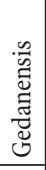 & 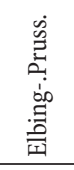 & 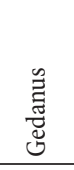 & 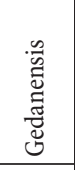 \\
\hline 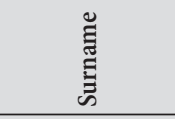 & $\begin{array}{l}\text { 节害 } \\
\text { 을 } \\
\end{array}$ & 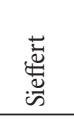 & 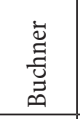 & 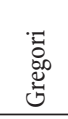 & 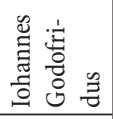 & 泀 & 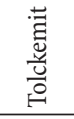 & 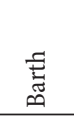 & 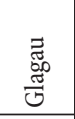 \\
\hline 䒕 & 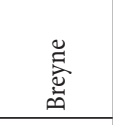 & 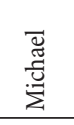 & $\begin{array}{l}\frac{\tilde{J}}{0} \\
\frac{0}{3} \\
\text { z }\end{array}$ & 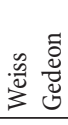 & 悹 & 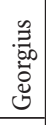 & 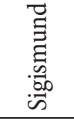 & 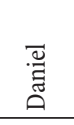 & 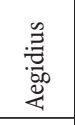 \\
\hline ڤิ & 6 & $\sim$ & $\stackrel{\sim}{\sim}$ & $x$ & $\stackrel{\infty}{-}$ & $\vec{\sim}$ & 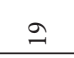 & $\beth$ & 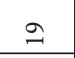 \\
\hline 莣 & $\stackrel{F}{\prime}$ & $\Xi$ & 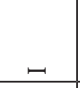 & 5 & 声 & $\check{\beth}$ & F & \$ & $\underset{\beth}{\Perp}$ \\
\hline 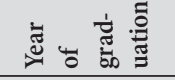 & $\stackrel{\widetilde{\Omega}}{\stackrel{\Omega}{I}}$ & $\stackrel{\Re}{\stackrel{\Omega}{\Omega}}$ & $\stackrel{2}{\stackrel{2}{\Omega}}$ & $\stackrel{2}{\triangleq}$ & $\stackrel{\infty}{\stackrel{2}{\Omega}}$ & $\Xi$ & $\stackrel{\beth}{\Xi}$ & $\stackrel{20}{\Xi}$ & $\stackrel{n}{\Xi}$ \\
\hline 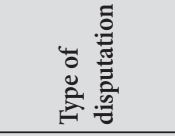 & 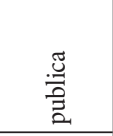 & 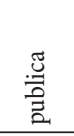 & 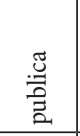 & 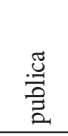 & 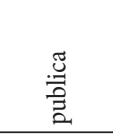 & 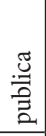 & 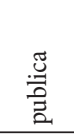 & 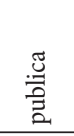 & 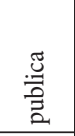 \\
\hline 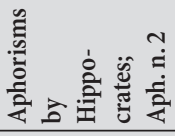 & $\begin{array}{l}\vec{r} \\
\ddot{0} \\
\infty \\
m \\
m\end{array}$ & $\begin{array}{l}0 \\
\dddot{y} \\
\& \\
\curvearrowleft \\
\end{array}$ & 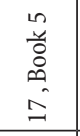 & $\begin{array}{l}+ \\
\text { मे } \\
\varnothing 0 \\
\infty \\
\infty\end{array}$ & 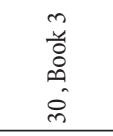 & 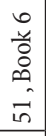 & 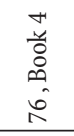 & $\begin{array}{l}\vec{z} \\
\text { ¿े } \\
\cong \\
\text { ते }\end{array}$ & 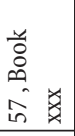 \\
\hline 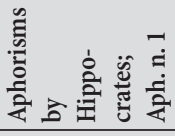 & $\begin{array}{l}\vec{y} \\
\stackrel{0}{0} \\
\curvearrowleft \\
\text { i }\end{array}$ & 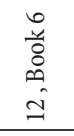 & 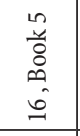 & 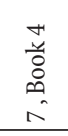 & $\begin{array}{l}m \\
\ddot{\circ} \\
\stackrel{0}{0} \\
\dot{\vec{\lambda}}\end{array}$ & 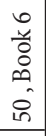 & 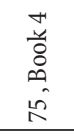 & 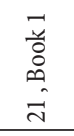 & 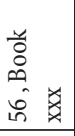 \\
\hline 气ิ & $\vec{n}$ & $\stackrel{10}{2}$ & $\wedge$ & $a$ & तี & $\wedge$ & $\stackrel{\bullet}{0}$ & ి & $\tilde{\sim}$ \\
\hline 声 & - & 5 & - & 5 & $\nexists$ & $>$ & 貝 & 5 & 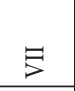 \\
\hline ¿ँّ & 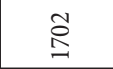 & $\stackrel{\Re}{\cong}$ & $\stackrel{\llcorner}{\stackrel{2}{\Omega}}$ & $\stackrel{2}{\varrho}$ & $\stackrel{\infty}{\stackrel{2}{\Omega}}$ & $\vec{\Xi}$ & $\stackrel{\Xi}{\Xi}$ & $\stackrel{20}{\Xi}$ & $\stackrel{20}{\Xi}$ \\
\hline
\end{tabular}




\begin{tabular}{|c|c|c|c|c|c|c|}
\hline 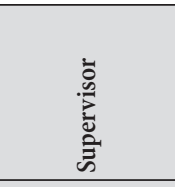 & 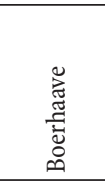 & $\begin{array}{l}\text { 营 } \\
\text { 惫 } \\
\end{array}$ & $\widetilde{\Xi}$ & 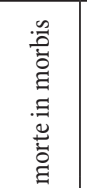 & & \\
\hline$\stackrel{\Xi}{\Xi}$ & 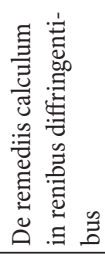 & 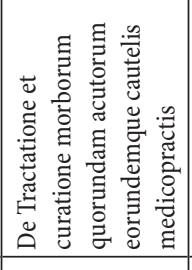 & 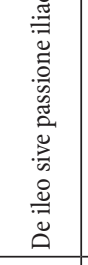 & 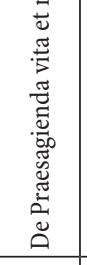 & 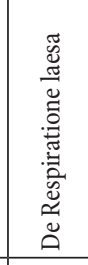 & 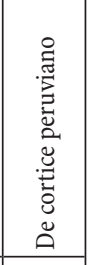 \\
\hline 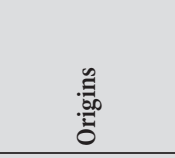 & 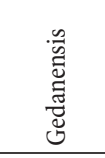 & 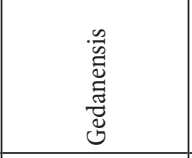 & 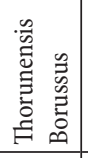 & 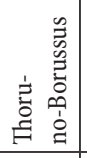 & 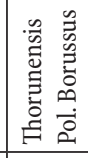 & 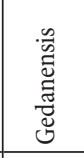 \\
\hline 莒 & 葷 & 䓂 & 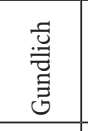 & 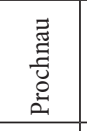 & 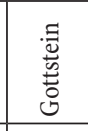 & 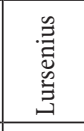 \\
\hline 善 & 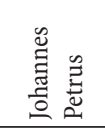 & 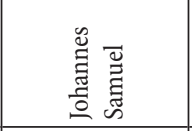 & 急 & 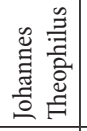 & 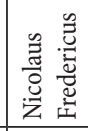 & 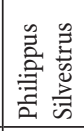 \\
\hline 离 & $=$ & $\cong$ & $\vec{d}$ & - & $\cong$ & I \\
\hline 言 & 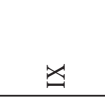 & 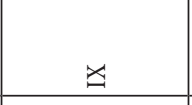 & 5 & $z$ & 5 & 5 \\
\hline 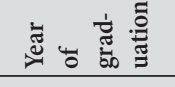 & 芯 & $\stackrel{\vec{\Xi}}{\Xi}$ & $\stackrel{\infty}{\subseteq}$ & 虽 & 워 & $\stackrel{\vec{n}}{=}$ \\
\hline 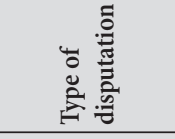 & $\begin{array}{l}\frac{\pi}{\tilde{n}} \\
\frac{\bar{z}}{2} \\
\end{array}$ & 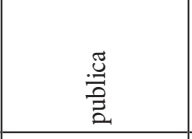 & 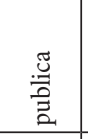 & $\begin{array}{l}\text { 䄈 } \\
\text { 言 } \\
\end{array}$ & $\begin{array}{l}\text { 䗷 } \\
\text { 言 } \\
\end{array}$ & 䄈 \\
\hline 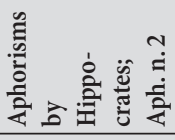 & 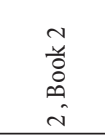 & 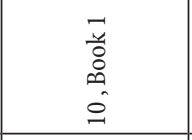 & 兑 & 关 & $\ddot{x}$ & 盛 \\
\hline 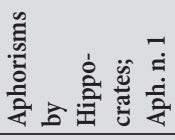 & 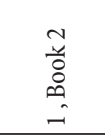 & 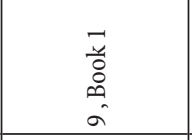 & 关 & . & 关 & 若 \\
\hline$\stackrel{\vec{\partial}}{\stackrel{\Delta}{*}}$ & $\Rightarrow$ & 6 & 㢆 & 尊 & $\ddot{r}$ & 尊 \\
\hline 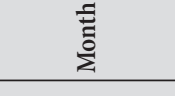 & 声 & 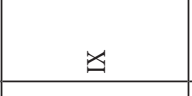 & 㢂 & 兑 & 羞 & 当 \\
\hline こ्र & $\stackrel{\text { I }}{\Xi}$ & 芯 & 莫 & 莫 & 莫 & 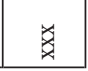 \\
\hline
\end{tabular}




\title{
WYDZIAE MEDYCZNY UNIWERSYTETU LEJDEJSKIEGO I JEGO ABSOLWENCI Z RZECZYPOSPOLITEJ POLSKO-LITEWSKIEJ
}

\author{
UWAGI WSTĘPNE
}

STRESZCZENIE

Począwszy od pierwszych lat XVII wieku Wydział Medyczny Uniwersytetu Lejdejskiego cieszył się dużym zainteresowaniem młodych protestantów pochodzących z Rzeczypospolitej Obojga Narodów. Wielu immatrykulowanych na Academia Lugduno-Batava studentów z Gdańska, Leszna czy Wilna właśnie tam uzyskało stopień doktora. Po zakończeniu wieloletnich peregrynacji medycznych zakładali praktyki w rodzinnych miastach oraz - jak na przykład Christoph Gottwald z Gdańska i Simon Schultz z Torunia - przekuwając zdobytą wiedzę w teksty naukowe.

\section{DIE MEDIZINISCHE FAKULTÄT DER UNIVERSITÄT LEIDEN UND IHRE ALUMNI AUS POLEN-LITAUEN}

EINIGE VORBEMERKUNGEN

ZUSAMMENFASSUNG

Seit Anfang des 17. Jahrhunderts zog die Medizinische Fakultät der Universität Leiden eine große Anzahl junger Protestanten aus Polen-Litauen an. Zahlreiche immatrikulierte Studenten aus Danzig, Lissa oder Wilna haben an der Academia Lugduno-Batava promoviert. Nach Abschluss der mehrjährigen medizinischen Ausbildungsreisen richteten die Alumni in ihren Heimatstädten Arztpraxen ein und verwandelten - wie Christoph Gottwald aus Danzig und Simon Schultz aus Thorn - das erworbene Wissen in wissenschaftliche Abhandlungen.

\section{THE MEDICAL FACULTY AT THE UNIVERSITY OF LEIDEN AND ITS GRADUATES FROM THE POLISH-LITHUANIAN COMMONWEALTH}

SOME INTRODUCTORY REMARKS

SUMMARY

From the very beginning of the $17^{\text {th }}$ century, the Medical Faculty at the University of Leiden attracted a vast number of young religious dissenters from the Polish-Lithuanian Commonwealth. Numerous students from Danzig, Lissa or Vilna, earned their MDs at the Academia Lugduno-Batava. After completing their multi-annual educational and medical travels, the alumni set up medical practices in their countries and, as Christoph Gottwald from Danzig and Simon Schultz from Thorn, they transformed the acquired knowledge into scientific testimonies published. 


\section{SŁOWA KLUCZOWE / SCHLAGWORTE / KEYWORDS}

- historia medycyny; peregrinatio medica; Lejda; Prusy Królewskie; XVII-XVIII wiek; Christoph Gottwald; Simon Schultz

- Geschichte der Medizin; peregrinatio medica; Leiden; Königlich Preußen; 17.-18. Jahrhundert; Christoph Gottwald; Simon Schultz

- history of medicine; peregrinatio medica; Polish Prussia; Leiden; 17-18 ${ }^{\text {th }}$ c.; Christoph Gottwald; Simon Schultz

\section{BIBLIOGRAFIA / BIBLIOGRAFIE / BIBLIOGRAPHY}

\section{ŹRÓDŁA ARCHIWALNE / ARCHIVALISCHE QUELLEN / ARCHIVAL SOURCES}

Archiwum Państwowe w Gdańsku: 300,R/ H,q2; 300,42/258.

Biblioteka Politechniki Gdańskiej: D.a.85, vol. II.

British Library: Sloane Ms, 3321; Sloane Ms, 3322; Sloane Ms, 4039; Add Ms 4435.

Rijksmuseum Boerhaave/Universitaire Bibliotheken Leiden: BOERH a 527.

Universitaire Bibliotheken Leiden: ASF 7-15; ASF 414-415; ASF 357-358.

\section{ŹRÓDłA DRUKOWANE / GEDRUCKTE QUELLEN / PRINTED SOURCES}

Abbildung///Eines erschrecklichen//Meer=Wunders//So am Ende deß 1661. Jahrs in Holland zwischen Schevelingen und Catwick//auff=See gefangen worden, (1662).

Album studiosorum Academiae Lugduno Batavae MDLXXV-MDCCCLXXV: accedunt nomina curatorum et professorum per eadem secula, ed. G. du Rieu, (1875).

Bartholin T., De peregrinatione medica. On medical travel, (1961).

[Breyne J.], Prodromus fasciculi rariorum plantarum, Anno M.DC.LXXIX. in hortis Celeberrimis Hollandiae, praefertim Incomparabili \& Nobilissimo illo Florae Pandocheo Illustrissimi atqve Excellentissimi Domini, Domini Hieronymi van Beverningk etc. observatarum a Jacobo Breynio, Gedanensi [...], (1680).

[Breyne J. P.], II. Epistola D. J. Phil. Breynij, M. D. Gedanensis, \& Reg. Societ. Lond. Sodal. ad. D. Hans Sloane, M. D. dictee Societatis Secretarium; varias observationes continens, in Itinere per Italiam suscepto, Anno 1703, in: Philosophical Transactions of the Royal Society of London, 27 (1710).

Encyclopaedia, Septem Tomis Distincta, ed. J.-H. Alsted, (1630).

Freytag A., Dispvtatio Medica inavgvralis de Apoplexia: quam cum bono deo ex avthoritate [...] Petri Cvnaei [...] Academiae Lugdunensis Rectoris [...] pro Gradu Doctoratus summis in Arte Medica [...] (1632).

[Gottwald Ch.], Disputatio VIII. De vasis lymphaticis ac lympha. Resp. Christophoro Gottwald Dantisco-Prusso, 19. Mart. 1661, in: F. De Le Boe Sylvii, Medicinae Practicae in Academia Lugduno-Batava Professoris. Disputationum Medicarum Decas. Primarias corporis humani functiones naturales. nec non febrium naturam, ex anatomicis. practicis etc.; chimicis experimentis deductas. complectens: Omnibus ad Leidense exemplar fideliter conformatis, (1674). 
[Gottwald Ch., Breyne J. P], Musaeum Gottwaldianum, (a. 1714).

Kohfeldt G., Eine akademische Ferienreise von Rostock bis Königsberg im Jahre 1694, in: Baltische Studien, 9 (1905).

O'Connor B., The history of Poland; vol. 2 in several letters to persons of quality, giving an account of the antient and present state of that kingdom, historical, geographical, physical, political and ecclesiastical [...]: with sculptures, and a new map after the best geographers: with several letters relating to physick / by Bern. Connor [...] who, in his travels in that country, collected these memoirs from the best authors and his own observations; publish'd by the care and assistance of Mr. Savage, (1698).

[Schultz S.], Disputatio medico de plica Polonica. Quam auspice Deoter opt. max. praesidia [...] in florentissima Lugduno-Batava Academia public examine subjicit Simon Schultz, Thorunio-Prussus a.d.13 Julii, (1648).

Schultz S., Obs. CXXXVIII: De Plica Explicata, in: Miscellanea Curiosa Medico-Physica Academiae Naturae Curiosorum, Sive Ephemeridum Medico-Physicarum Germanicarum, 6/7 (1675/1676).

Schultz S., Obs. LX: Infimus Venter Totus Scirrhosus, in: Miscellanea Curiosa, sive Ephemeridum Medico-Physicarum Germanicarum Academiae Naturae Curiosorum, 2 (1671).

Schultz S., Obs. LXI: Phantasia Et Terror In Gravida Faetui Valde Noxia, in: Miscellanea Curiosa, sive Ephemeridum Medico-Physicarum Germanicarum Academiae Naturae Curiosorum, 2 (1671).

Schultz S., Obs. LXII: Corporis Epilepsia Extincti Anatomica Administratio, in: Miscellanea Curiosa, sive Ephemeridum Medico-Physicarum Germanicarum Academiae Naturae Curiosorum, 2 (1671).

Schultz S., Obs. LXIII: Remedium plebejorum ad calculum, in: Miscellanea Curiosa, sive Ephemeridum Medico-Physicarum Germanicarum Academiae Naturae Curiosorum, 2 (1671).

Schultz S., Obs. X: Idiosyncrasia Naturalis, Aranearum Comestio innoxia, in: Miscellanea Curiosa, sive Ephemeridum Medico-Physicarum Germanicarum Academiae Naturae Curiosorum, 2 (1671).

Seger G., Obs. XXXII: De Anatome Solemni Furis Quinquagenarii, in: Miscellanea Curiosa Medico-Physica Academiae Naturae Curiosorum, 8 (1677).

Seger G., Synopsis Physicae Antiquo-Novae, editio secunda, (1677).

Vitae medicorum Gedanensium Ludwiga von Hammena i Valentina Schlieffa, ed. B. Siek, A. Szarszewski, (2015)

Zeemonster gevangen tussen Scheveningen en Katwijk, 1661 Een Wonderlyck Zee-Monster te sien, (1661).

\section{LITERATURA / LITERATUR / LITERATURE}

Beukers H., Clinical teaching in Leiden from its beginnings until the end of the $18^{\text {th }} \mathrm{c}$., in: Clinical Teaching, Past and Present, Clio Medica, 21 (1987-1988).

Bietenholz P. G., Daniel Zwicker (1612-1678). Peace, Tolerance and God the One and Only, (1997).

Bilikiewicz T., Jan Jonston (1603-1675). Żywot i działalność lekarska, (1931). 
Brzeziński T., Polskie peregrynacje po dyplomy lekarskie (od średniowiecza po odzyskanie niepodległości w 1918 r.), (1999).

Chachaj M., Podróże edukacyjne młodzieży z Prus Królewskich do Bolonii, Sieny i Perugii w XVI i XVII wieku, in: Prusy Książęce i Prusy Królewskie w XVI-XVIII wieku, ed. J. Wijaczka, (1997).

Cole F. J., The history of anatomical injections, in: Studies in the history and method of science, ed. C. Siger, 2 (1921).

Cunningham A., The Bartholins, the Platters and Laurentius Gryllus: the peregrinatio medica in the Sixteenth and Seventeenth Centuries, in: Centres of Medical Excellence? Medical Travel and Education in Europe, 1500-1789, ed. O. P. Grell, A. Cunningham, J. Arrizabalaga, (2010).

Davies D. W., The World of the Elseviers 1580-1712, (1954).

De Clercq P. R., At the Sign of the Oriental Lamp, the Musschenbroek Workshop in Leiden, 1660-1750, (1997).

De Ridder-Symoens H., The mobility of Medical Students from the fifteenth to the eighteenth centuries, in: Centres of Medical Excellence? Medical Travel and Education in Europe, 1500-1789, ed. O.P. Grell, A. Cunningham, J. Arrizabalaga, (2010).

De Sitter W., Short History of the Observatory of the University at Leiden, 1633-1933, (1933).

Fleischer A., Breyne's Botany: (Re-)Locating Nature \& Knowlegde in Danzig, in: Locations of Knowledge in Dutch Contexts, eds. F. J. Dijksterhuis, A. Weber, H. J. Zuidervaart, (2019).

Gąsiorowski L., Zbiór wiadomości do historyi sztuki lekarskiej w Polsce od czasów najdawniejszych, aż do najnowszych, 1-4, (1839-1855).

Grell O., 'Like the bees, who neither suck nor generate their honey from one flower': the significance of the peregrinatio academica for Danish medical students of the late sixteenth and early seventeenth centuries, in: Centres of Medical Excellence? Medical Travel and Education in Europe, 1500-1789, ed. O. P. Grell, A. Cunningham, J. Arrizabalaga, (2010).

Grell O., Three seventeenth-century manuals on how and where to study medicine, in: Medicine, Natural Philosophy and Religion in Post-Reformation Scandinavia, ed. O. Grell, A. Cunningham, (2016).

Haye T., Lorenz Gryll (d. 1560): a traveller in the Service of Medical Training, in: Artes Apodemicae and Early Modern Travel Culture, 1550-1700, eds. K. A. E. Enenkel, J. de Jong, (2019).

Kenkel H., Studenten aus Ost- und Westpreußen an außerpreußischen Universitäten vor 1815, anhand der gedruckten Matrikeln, (1981).

Kośmiński S., Słownik lekarzów polskich: obejmujący oprócz krótkich życiorysów lekarzy Polaków oraz cudzoziemców w Polsce osiadtych, dokladna bibliografią lekarska polską od czasów najdawniejszych aż do chwili obecnej, 1-2 (1883-1885).

Kucharski A., Theatrum peregrinandi. Poznawcze aspekty staropolskich podróży $w$ epoce późnego baroku, (2013).

Leitsch W., Das Leben am Hof König Sigismunds II. von Polen, 1-3 (2009).

Lindeboom G. A., Dog and Frog: Physiological Experiments at Leiden during the Seventeenth Century, in: Leiden University in the seventeenth century: An exchange of learning, ed. Th. H. Lunsingh Scheurleer, G. H. M. Posthumus Meyjes, (1975). 
Lindeboom G. A., Haller in Holland: het dagboek van Albrecht von Haller van zijn verblijf in Holland (1725-1727), (1979).

Lisowski W., Lekarze w służbie królów i hetmanów polskich, in: Lekarz Wojskowy, 62 (1986).

Miert D. van, Humanism in an Age of Science. The Amsterdam Athenaeum in the Golden Age, 1632-1704, (2009).

Nadolski B., Wyjazdy młodzieży gdańskiej na studia zagraniczne w XVII w., in: Rocznik Gdański, 24 (1965).

Novgorodowa D., Musaeum Gottwaldianum i jego losy w Rosji, in: Klio. Czasopismo poświęcone dziejom Polski i powszechnym, 46 (2018).

Onnekink D., Rommelse G., The Dutch in the Early Modern World: A History of a Global Power, (2019).

Pawlak M., Długokęcki W., Studia uniwersyteckie malborczyków do 1773 roku, (2004).

Pawlak M., Studia uniwersyteckie absolwentów Gimnazjum Elbląskiego w latach 1536-1772, in: Zeszyty Naukowe Uniwersytetu Mikołaja Kopernika. Nauki Humanistyczno-Społeczne, 24 (1967).

Pawlak M., Studia uniwersyteckie grudziądzan w epoce staropolskiej, in: Zeszyty Naukowe Wyższej Szkoły Pedagogicznej w Bydgoszczy. Studia Historyczne, 3 (1993).

Pawlak M., Studia uniwersyteckie młodzieży z Prus Królewskich w XVI-XVIII w., (1988).

Pawlak M., Wyjazdy młodzieży warmińskiej na studia uniwersyteckie w XVI-XVIII w., in: Komunikaty Mazursko-Warmińskie, 3 (1993).

Pękacka-Falkowska K., Freundtschafft die auch nach dem Tod wärt: Daniel Gödtke, Gerard Blaes i zootomia, in: Zapiski Historyczne, 85 (2020).

Pękacka-Falkowska K., Instrumenty chirurgiczno-anatomiczne i rytownicze gdańskiego lekarza Christopha Gottwalda (1636-1700), in: Klio. Czasopismo poświęcone dziejom Polski i powszechnym, 46 (2018).

Pękacka-Falkowska K., Jacob Breyne’s Hortisicci from 1659 and 1673, in: Zapiski Historyczne, 83 (2018).

Pękacka-Falkowska K., Matthias Ernst Boretius z Mazur i jego promocja doktorska w Niderlandach: z badań nad historia nauczania medycyny w XVIII wieku, in: Wybrane problemy historii medycyny. W kręgu epistemologii i praktyki, eds. A. Magowska, M. Owecki, K. Pękacka-Falkowska, (2020), pp. 205-221.

Pękacka-Falkowska K., Między Gdańskiem a Toruniem: Georg Seger i anatomia, in: Historia to (nie) fraszka. Studia ofiarowane Profesorowi Krzysztofowi Mikulskiemu w 60. Rocznice urodzin, eds. A. Zielińska, M. Targowski, (2020) [in press].

Pękacka-Falkowska K., Wokót kolekcji przyrodniczych w Rzeczpospolitej Obojga Narodów. Cz. 1. Christoph i Johann Christoph Gottwaldowie oraz ich gdańskie muzeum, in: Kwartalnik Historii Nauki i Techniki, (2) 2018.

Prätorius K. G., Wernicke J. E., Topographisch-historisch-statistische Beschreibung der Stadt Thorn und ihres Gebietes: die Vorzeit und Gegenwart umfassend, die Vorzeit und Gegenwart umfassend, (1832).

Prögler D., English Students at Leiden University, 1575-1650: 'Advancing Your Abilities in Learning and Bettering Your Understanding of the World and State Affairs', (2013).

Rossetti L., Dottorati polacchi dal 1600 al 1744 nel Sacro Collegio dei filosofi e medici di Padova, in: Relazioni tra Padova a la Polonia, (1964). 
Scherz G., Stensen's first dissertation, in: Journal of the History of Medicine and Allied Sciences, 15 (1960).

Sokół S., Polnische Mediziner in Basel im XVI.-XVII. Jahrhundert, in: Kwartalnik Historii Nauki i Techniki, 5 (1960).

Targosz K., Jan III Sobieski mecenasem nauk i uczonych, (2012).

Targosz K., Jana Sobieskiego nauki i peregrynacje, (1985).

Targosz K., Uczony dwór Ludwiki Marii Gonzagi (1646-1667), (2015).

Tering A., Riga Municipal Physician Nicolaus Witte von Lilienau (1618-1688): His Medical Views at the Crossroads of Tradition and Changes in Medical Teaching during his Student Years at Dutch Universities in the 1640s, in: Acta Baltica Historiae et Philosophiae Scientiarum, 2 (2014).

The paper museum of the Academy of Sciences in St. Petersburg c. 1725-1760: Introduction and Interpretation, ed. R. Kistemaker et al., (2005).

Thijssen L., Polska Niderlandy: 1000 lat kontaktów, (2003). 


\section{DISPUTATIO MEDICA \\ $D E$ \\ PLICA POLONICA. \\ 2VAM}

Aufpice DEO TER OPT. MAX.

P R E S I D D

Spectabili, Clarifsimo o Experientiffimo Viro,

DN. ADOLFO VORSTIO Med.D. ejufdemque \& Botanices P. P. ac Horti Academici Præfecto.

\section{In florentifsima Lugduno-Batava Academis}

Publico examini fubjicit

SIM ON SCHVLTZ, Thorunio-Pruffus,

wad deem 13. Iulii, Loco horifque folitis.

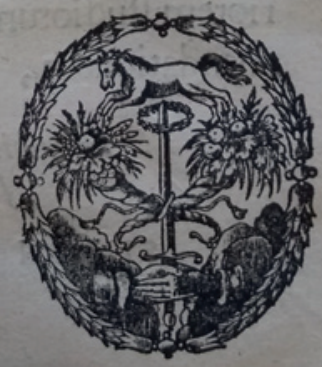

Lugduni Batavorum,

Excudebat SEVERINVS MATTHEI, I 648.

Fig. 1a. 


\section{DISPVTATIO MEDICA}

D $E$

\section{PLICA POLONICA.}

Crtum est, quamlibet ferè regionem aliquid babere, quod fibi jure quodam modo fuo vendicare videtur: foc quoque of morbos quo dam nornullis Provinciis it a familiares effe, ut ejus quafi proprii dicantur, in aprico est. SPpellant hos propter communem aliquam cau fam ivonpiss, ac $f i$ dicas, vernaculos five indiginas of proprios. Talis morbus, à Plinio sceletyrbe of stomacace, à recentioribus Scorbutus dictus, ad Septentrionalis maris littus babitantibus communis eft. Talis 2 eapolitanis podagra; Alpinarum regionum incolis, Hijpaniaque finitimis bronchocele effe putatur. Galenus Alexandrinis elephantiafin familiarem foripfit. Defingulorum natura varii varia obfervarunt. Affectum, cui à capillorum ceu glutine quodam invifcatione \& invicem.complicatione, Plice nomen tribuitur, \& qui Polonis peculiaris eft, vix quidam ex obfervatione propria, pauci ex relatione aliorum bucusque confideraverunt. Hins naturâcjus nondum planè perjpecta, auxilia per indicationes invenire, baud facile eft. Hanc plicam nos, auxiliante Numine, explicare annitentes, ufitata hactenus methodo ab ejus nomine exordium faciemus.

$$
\text { Positio } I \text {. }
$$

ICtus eft hic morbus plica, quod capillos inter feplanè complicet : plica Polonica, quod Polonis imprimis eis qui inter Ungariam \& Pocutium habitant, \& his fipoftea endemius factus eft. Schenckius quidem Lib. I. Obfery.

Fig. 1b. 


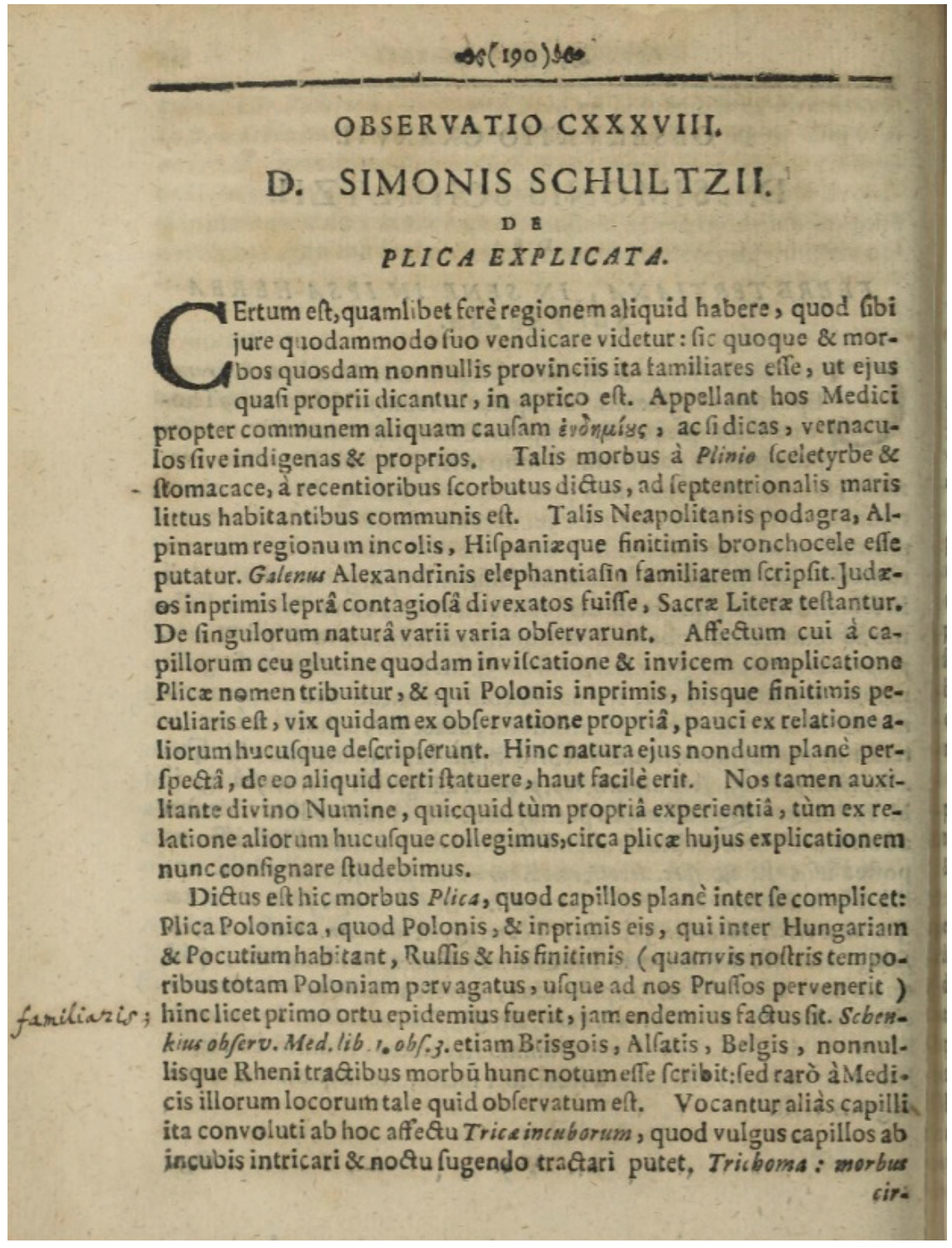

Fig. 1c.

Fig. 1a-c: Two papers on Polish pile (plica polonica) by Simon Schultz; his medical disputation published in 1648 (a, b) and an observatio published in 1675 (c). Source: see footnotes n. 57 and 59 . 


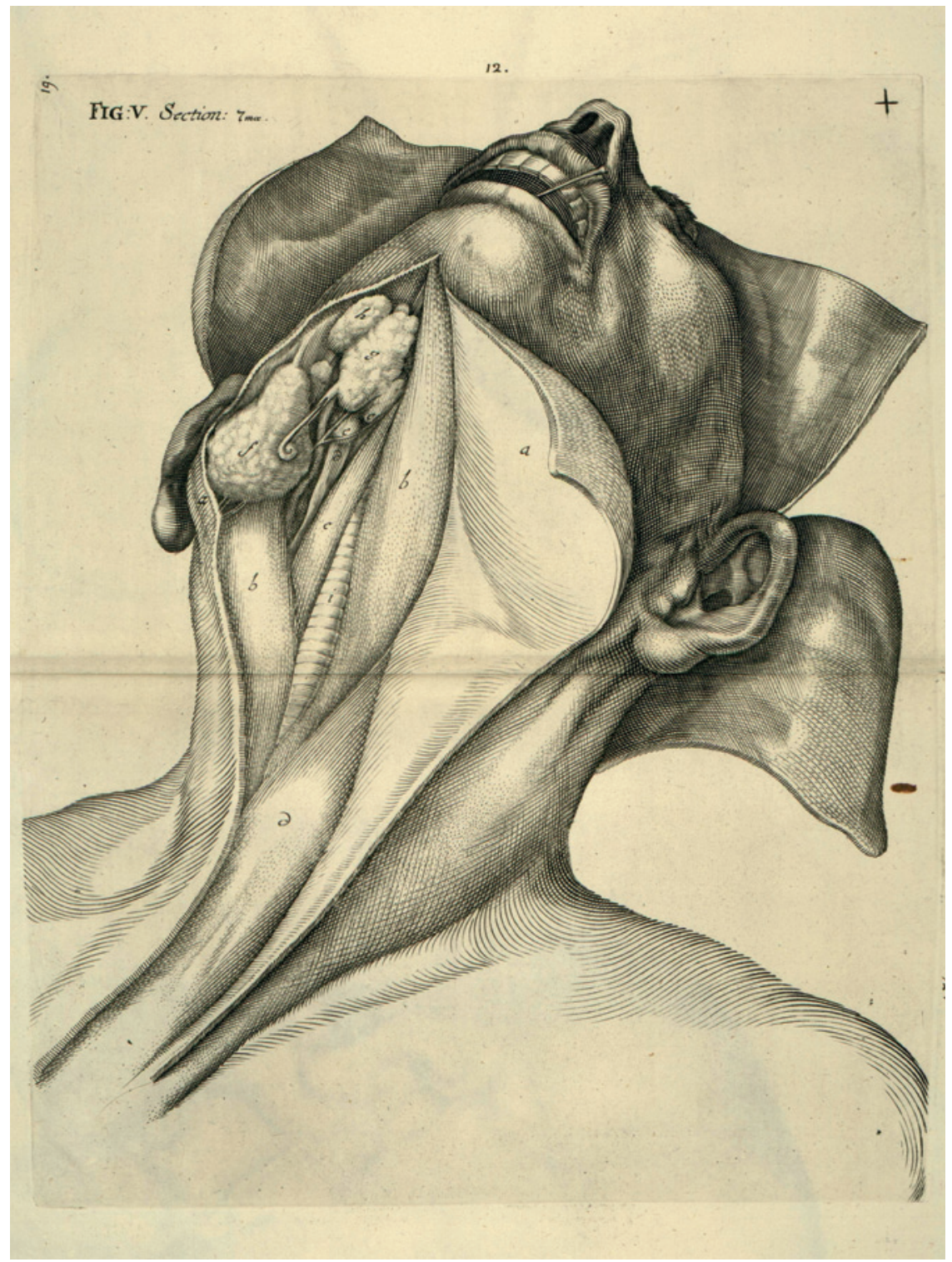

Fig. 2: A copperplate etching by Christoph Gottwald together with its description. Source: UBL, call number BOERH a 527 (description); Musaeum Gottwaldianum, Collection Bnu en dépôt à l'Université de Strasbourg; https://docnum.unistra.fr/digital/collection/coll13/ $\mathrm{id} / 43952$ (etching). Original caption under the illustration: Tab. + // Fig. V. ostendit glandulas maxilla. inferioris, illarumq. ductum salivalem, Warthonianum dictum, qui exit circa radicem ligamenti lingua. inferius. Distant a se [crossed out: imp] invicem duorum illorum ductuum utriusq. lateris insertiones, latitudine calami scriptorii crassioris 


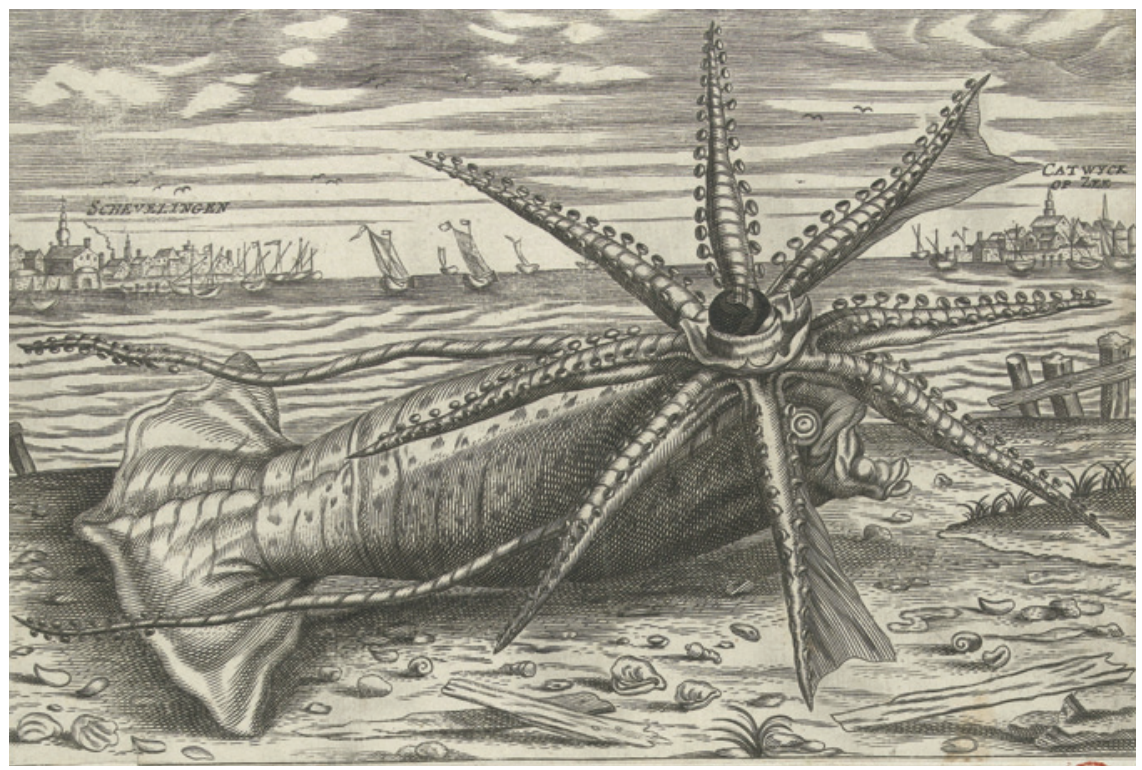

Fig. 3: Sea monster found between Scheveningen and Katwijk, The Netherlands, in 1661 (attributed to Salomon Savery) (detail). Source: Rijks Museum, Zeemonster gevangen tussen Scheveningen en Katwijk, 1661

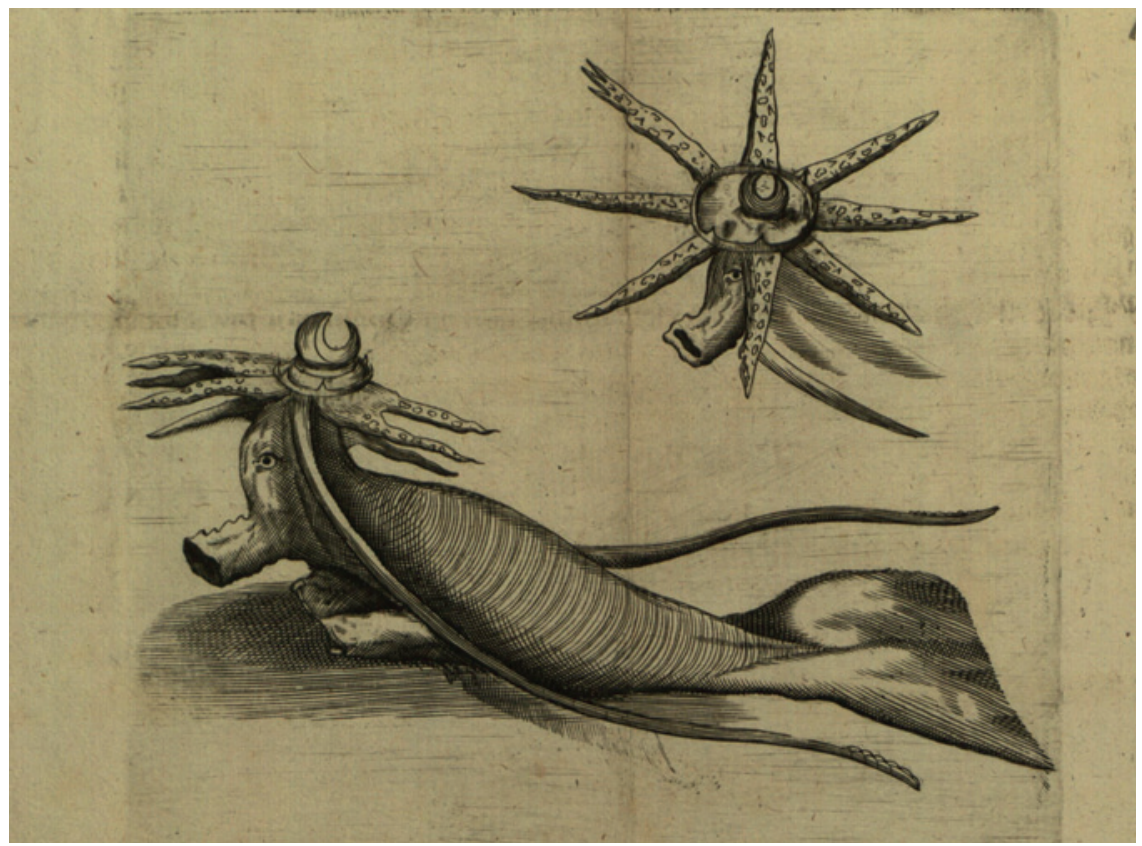

Fig. 4: Sea monster found between Scheveningen and Katwijk (published by Christoph Lochner) (detail). Source: Abbildung///Eines erschrecklichen//Meer=Wunders//So am Ende deß 1661. Jahrs in Holland zwischen Schevelingen und Catwick//auff=See gefangenworden, (1662) 


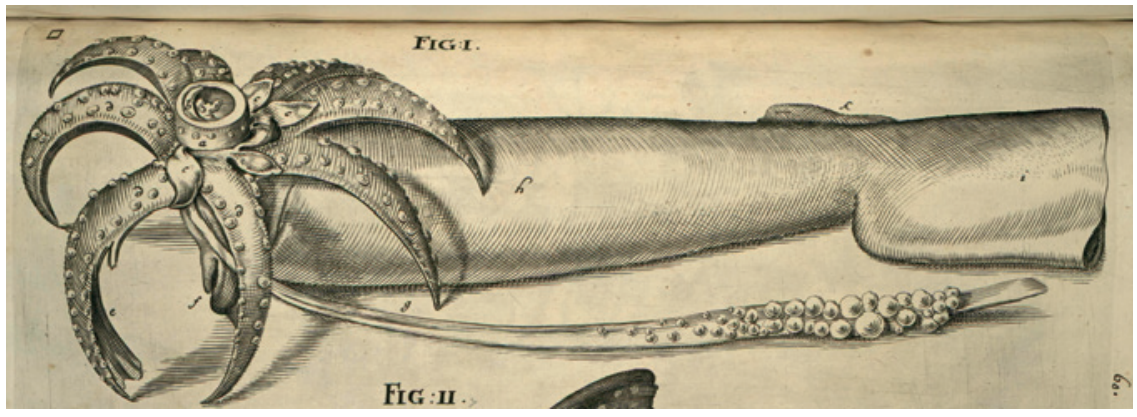

Fig. 5: Sea monster found between Scheveningen and Katwijk (depicted by Christoph Gottwald) (detail). Source: Musaeum Gottwaldianum, Collection Bnu en dépôt à l'Université de Strasbourg

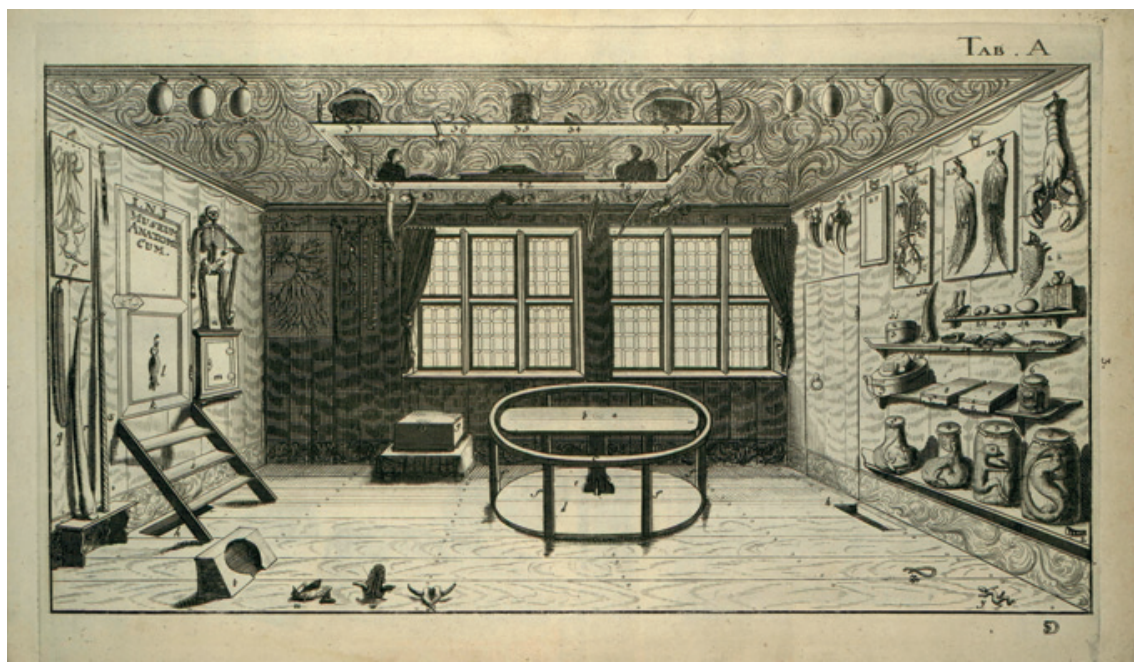

Fig. 6: Christoph Gottwald's private anatomical chamber in Danzig. Source: Musaeum Gottwaldianum, Collection Bnu en dépôt à l'Université de Strasbourg 


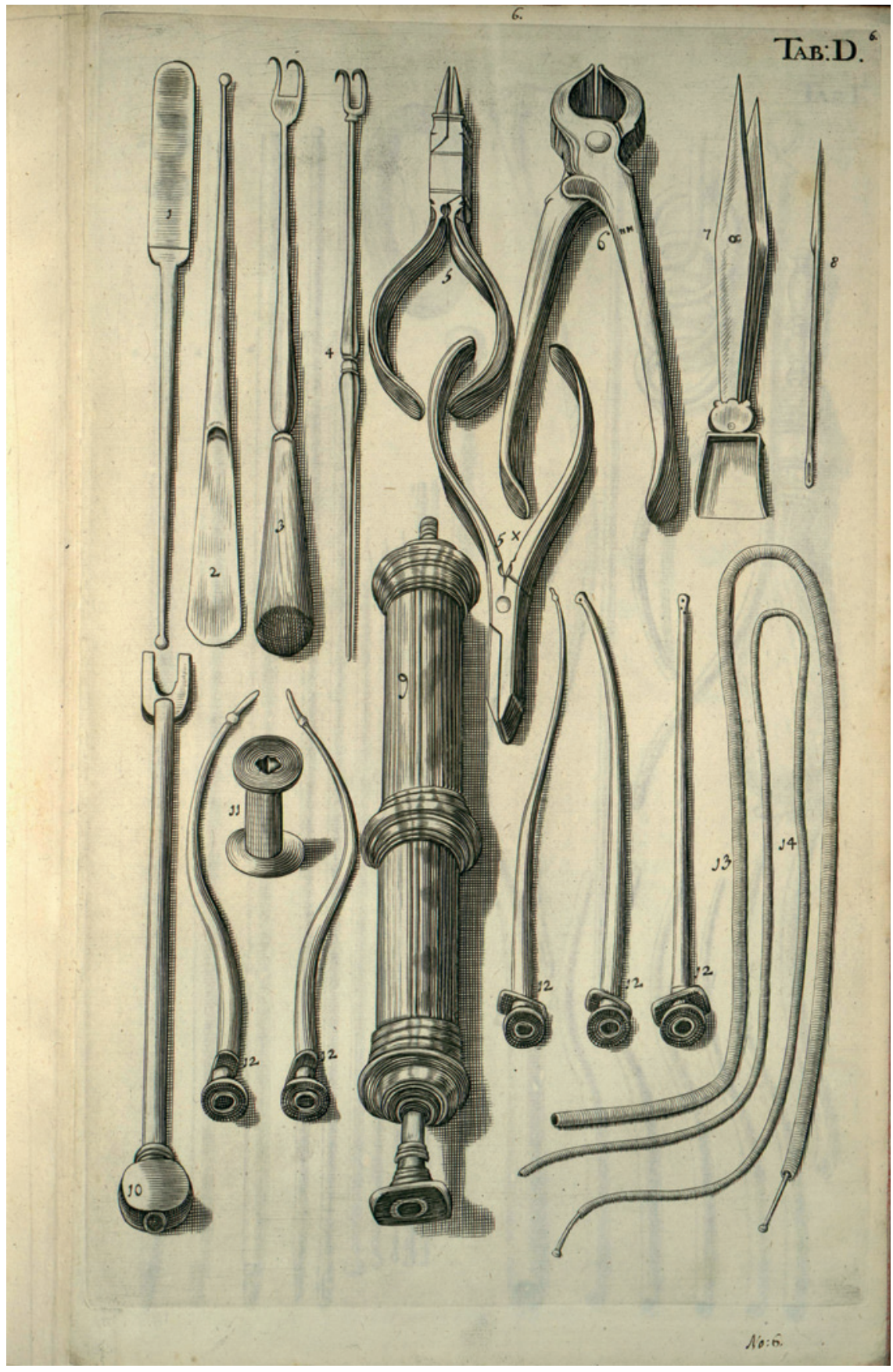

Fig. 7: Syringe with tubings by Christoph Gottwald. Source: Musaeum Gottwaldianum, Collection Bnu en dépôt à l'Université de Strasbourg 